\title{
سؤال الجنوسة وثقافة الابداع النسوي العربي لميعة عباس عمارة انموذجآ
}

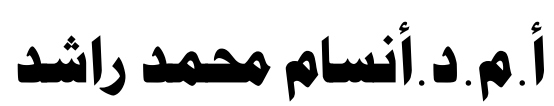

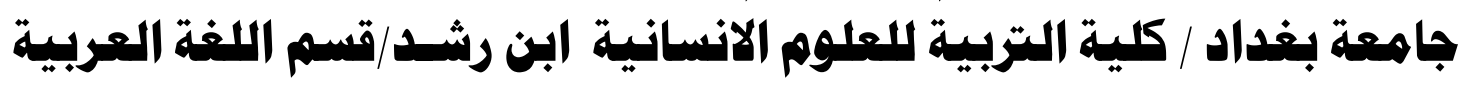 ansam.rashed2014@yahoo.com}

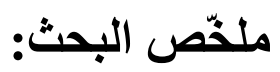

ينقسم بحثا سؤال الجنوسة على جز أين متكاملين، يتجه الأول منهما لقراءة الخطاب

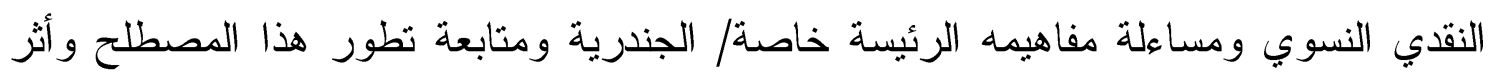
النقد النسوي في ترسيخ الهوية الابداعية للمر أة وان الكتابة الاثثوية مصطلح مقابل لكتابة الرجل الرئل

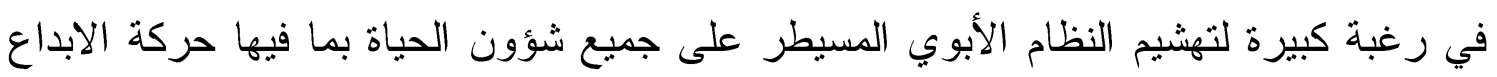
و الكتابة.

ويريد بحثنا في جزئه المتم تفكيك ماهية الجنوسة منتقيا تجربة ابداعية عربية واخترنا

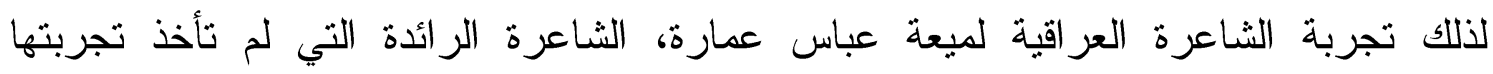

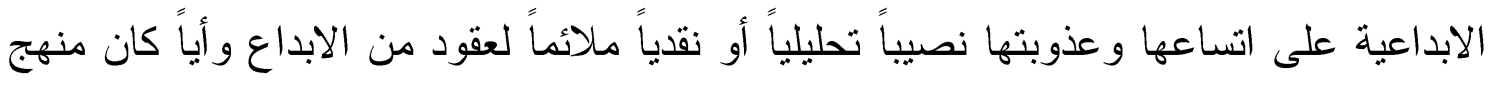

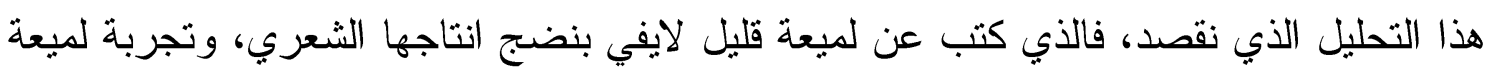

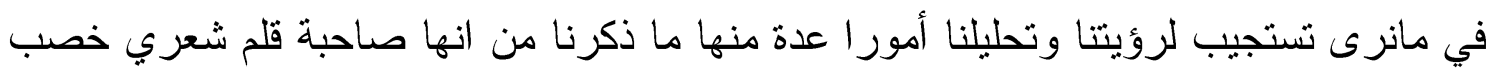

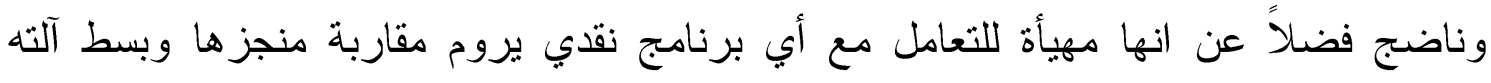

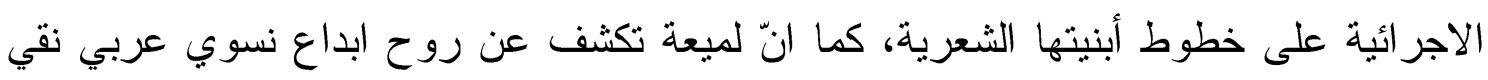

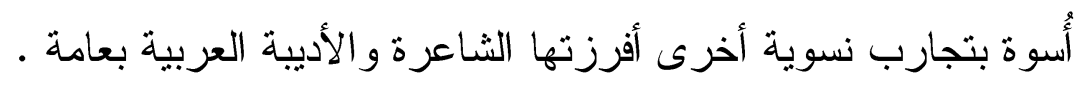

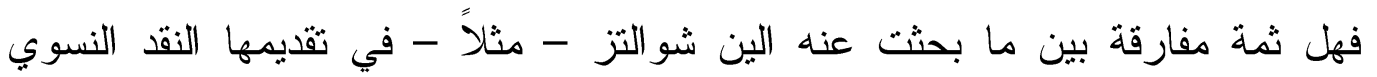
وتتظيرها له وبين عجلة الابداع النسوي العر اقي، وإنها رؤية في مطلق الأحوال، لأننا سنقام

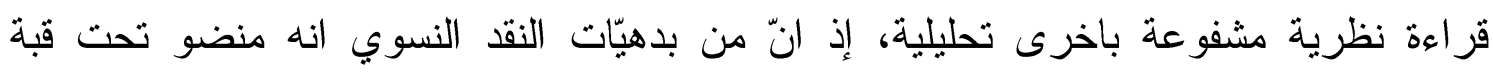

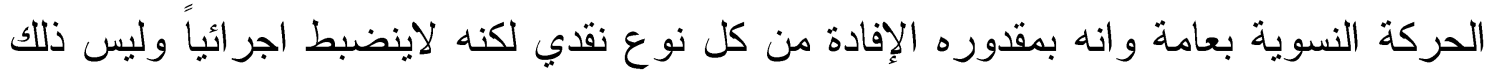




\section{ا - هابعد الحداثة: عهد الأنوثة وسياسة الجندرية}

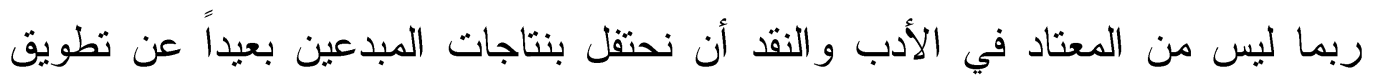

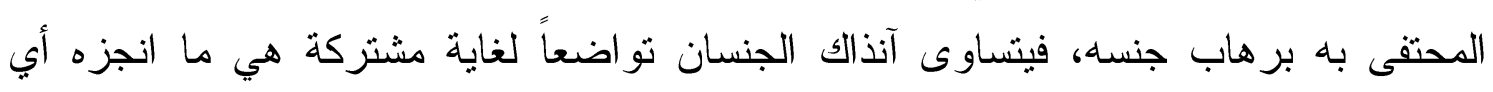

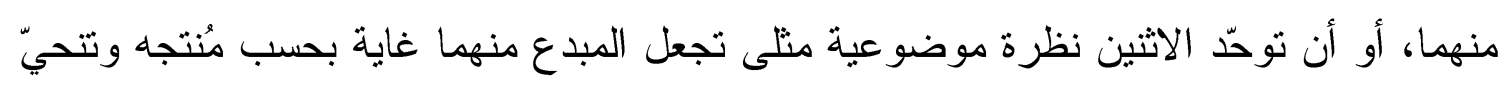

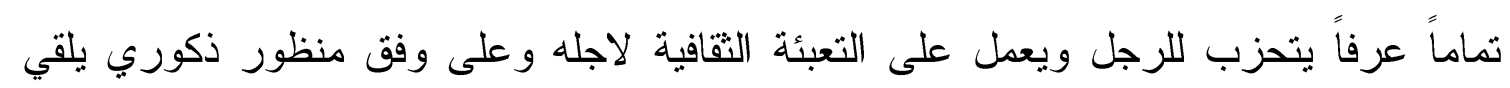

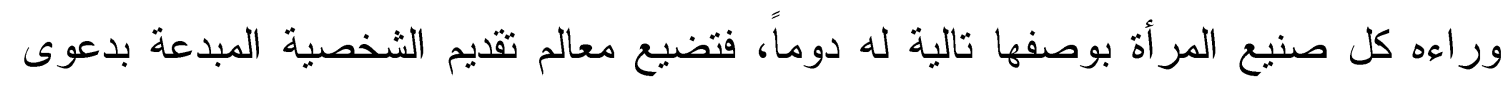

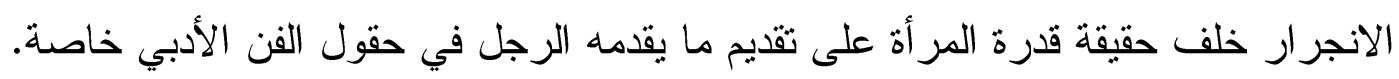

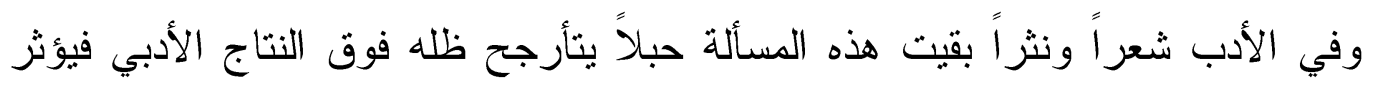

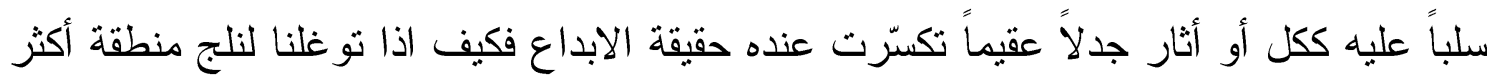
عمقاً حالما تحدثا عن خصوصية نسوية نقية تجمع خطوطها الخاصة لتكوّز ها داخل دائرة

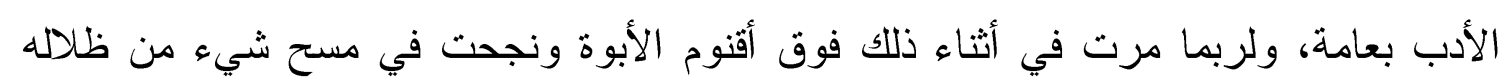
غير القابلة للمر اجعة.

فهل من الحتمي أن يكون تعدد الصوت في خطاب مفرد ضرورة لاختلاف هذا الخطاب

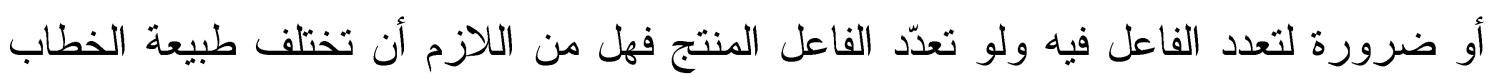

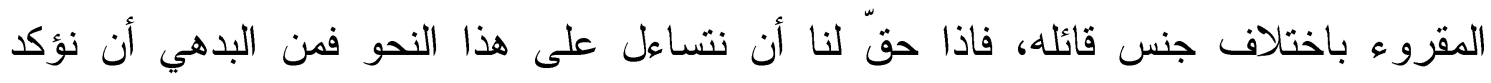

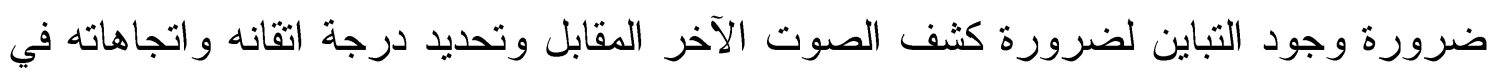
الكتابة.

و لاننسى كذللك أن ارادة المتكلم صانع الخطاب لابد من أن تقطع اشواطاً زمنية ليست

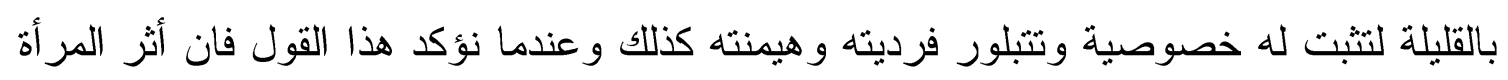
وخطابها سيطلان بقوة لأنها تداولياً قسيم الرجل في كل خطاب، ومنجز هانها الابداعي الأدبي كان

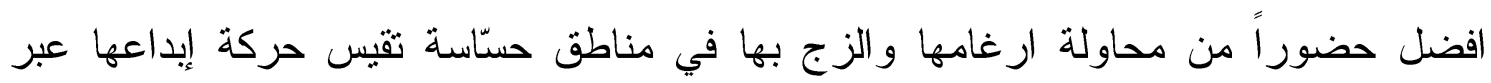

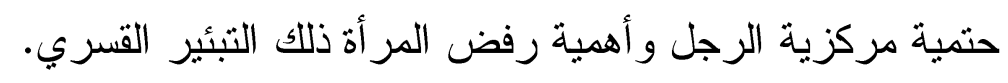

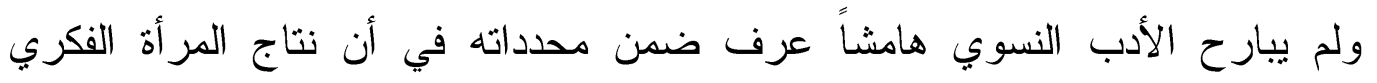
و الابداعي غير مسموح له بأن يصطف في الطرف المقابل لأي خطاب ابداعي سيكون مسؤو لاً

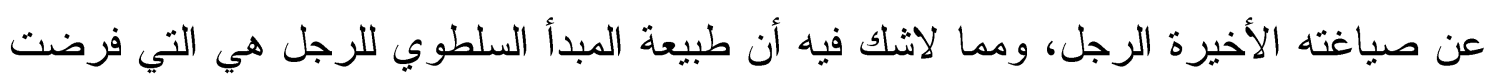

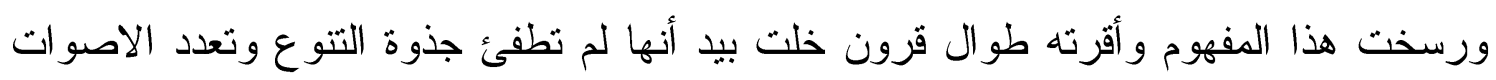
وفرضية التغاير وأدلجة تلك النظرة قد تعاملت معها المبدعات على لثلى اختلافهن تعاملاً ايجابياً،

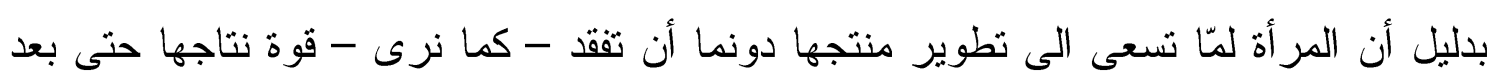


عرضه على طاولة الثو ابت السالف ذكرها، كما أنها مأخوذة بحركة التعديل و التجديد و الابتعاد عن أي تتمبط لفكر ها الأدبي خاصة. ومن وجهة أخرى نتساءل هل ستبقى الذات الانثوية مختفية تحت عباءة الخطاب

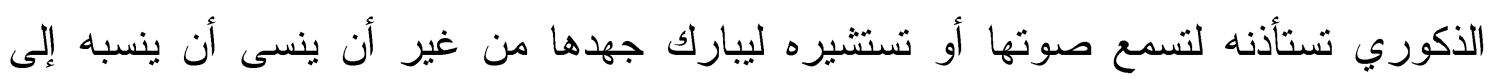
سلطة أبوية عليا وفي هيأة هبات مستترة غير ظاهرة، وإن سمح بذلك انتجت المرأة خطاباً أدبياً

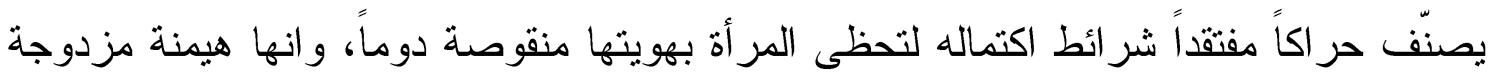

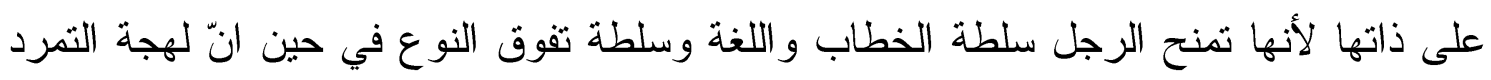

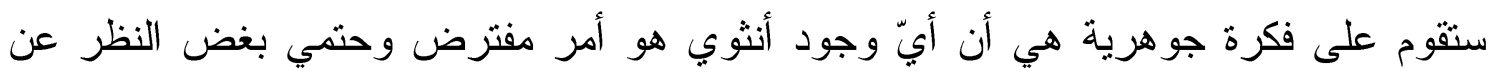

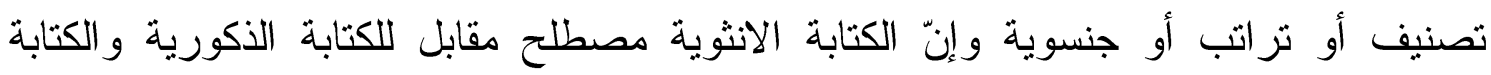

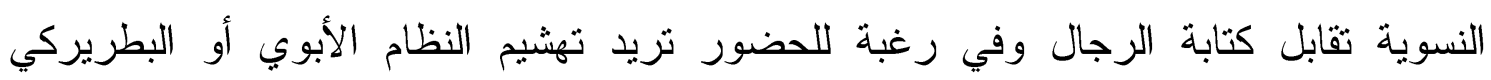
المفروض في جميع نو احي الحياة ومنها الكتابة وحركة الابداع النسوي.

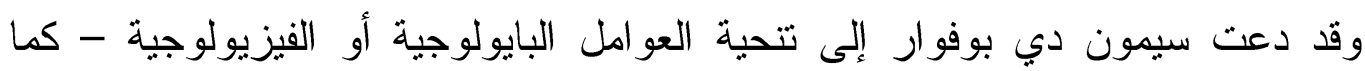

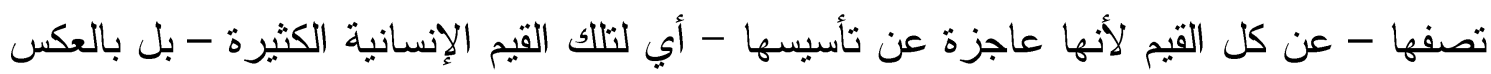

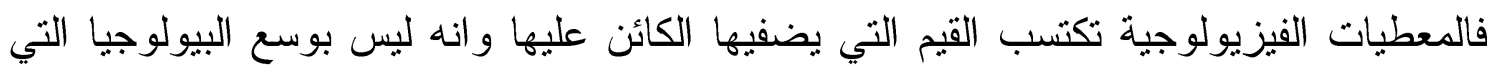

تقسم الكون نوعين ذكر و أنثى أن تجيب عن السؤال المهم لماذا تكون المر أة الجنس الآخر (1).

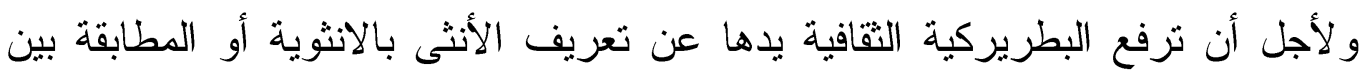

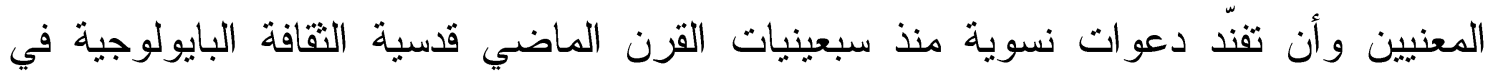

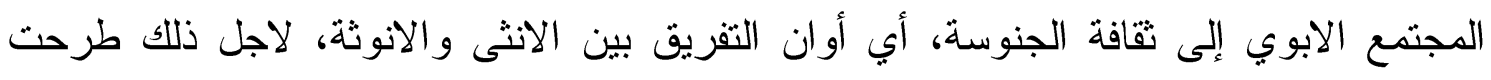

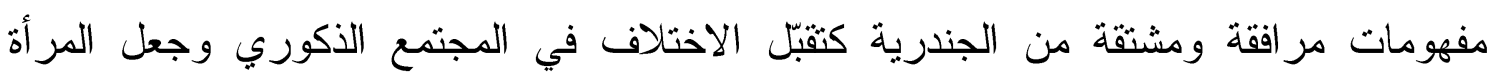

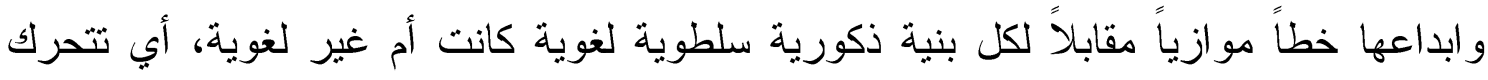

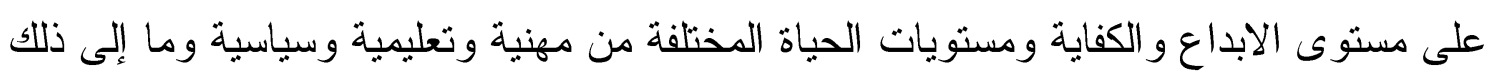
وذللك ما جلبته الجندرية. انها تقانة تعديل الادوار في الحياة لكي لاييقى التشريح الجسدي للنوع هو ذاته التشريح

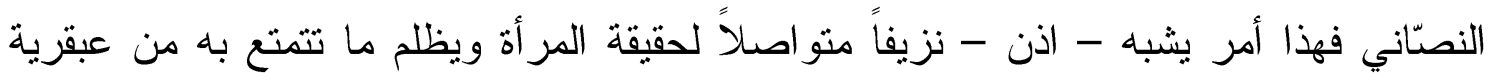

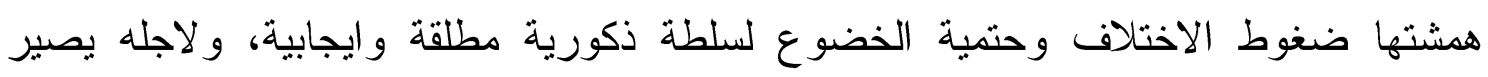

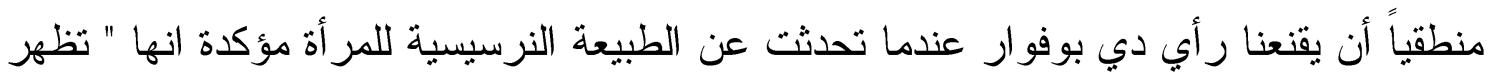

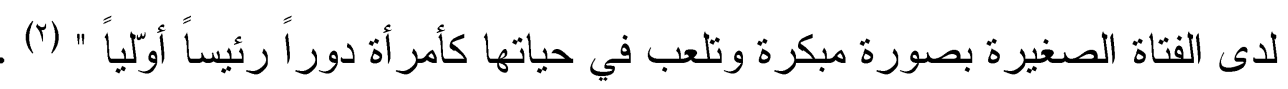


انّ تمتّع المر أة بهذه الطبيعة جعلها تحب وتقدس ذاتها إلى حّد انها اليوم وفي زمان ما بعد الحداثة انضجت فعاليات نسوية / حركات نسوية ببر امج سياسية وثقافية مُقاومِة للرومانسية الذكورية لكنها لاتوصف بانها " أما منسقة مع التفكير مع ما بعد الحداثة أو حتى مثل عنه " (r)، في حين يمكن القول " انهما معاً يؤلفان أكبر قوة وحيدة وفِّالة في تغيير الاتجاه الذي كانت تسير فيه المابعد حداثية الذكورية " (£)، وتمضي لندا هنشيون لتؤكد إنّ انشغالات ما بعد الحداثة بالنسوية ذات بعد مزدوج فاذ تمضي النسويات في اعادة النظر في الفكرة الكلية الإنسانية التي يمثلها الرجل فانها ثقدم طريقة فعّالة للمبدعات النسويات في العمل بحرية ابداعهن داخل أشكال

الخطاب الأبوي المسيطر (ن).

وفي تواصل لذات الأفكار يجيء التأكيد أن النظرية النسائية الأمريكية موضوعها الرئيس والسياسي هو " المرأة البيولوجية في حين تعد النظرية النسائية الأوربية معالجة موضوعها موقف بنيوي تحتله الأنثى والجسد والآخر"(")، و علبه أقرّت النظرية النسائية بظهور الهامشي و التابع و المغيّب و اعتلائه سطحاً خارجياً ملموساً أقرّت ذلك توصيفاً للمر أة جعلها مستعرة خاضعة لسلطان الرجل وليس حتى تحليلاً سابقاً في النظرية النسائية الأمريكية ؛ فالمر أة انما هي جزء من العالم الثالث الذي يرزح مرغماً تحت سيطرة العالم الرأسمالي عملاً بالمنطق السياسي وهذا ما وجدته النساء المنشقات عن اليسار الخاضع لهيمنة الرجل واعتر افهّن

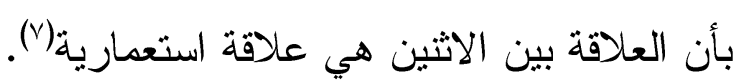
و هذا الربط نؤكده هنا ليفصح عن طبيعة انتساب النظرية النسوية والنسويات إلى الى حركات ما بعد حداثية بجدارة كما انها أثدّ تبار ر اديكالي وفقاً لمسارب سياسية مر افقة للانظمة الاقتصادية العالمية ، أي حركة البندول بين الماركسية وتهيمها بالر أسمالية العالمية، و لانريد أن نبتعد لأننا سنلقي بأسئلة الجنوسة في أبعد نقطة تصلها روح أنثوية تحاكي نشاطها الوجداني تجربة ابداعية مقرو عة ومكتملة. أثثة تو افق اذن بين المنحيين، بين ما تحققه غائية الجندرية ومطالباتها الكونية وبين جزء أنثوي تمثله دورة الابداع النسوي وما تفكر به تلك التجربة، ما بسمح به فقه الجنوسة لنا

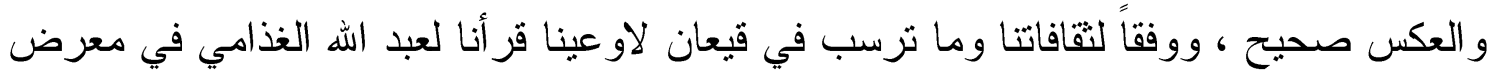
تحليله الثقافي قوله " وفيما بين هذين الحدّين التعسقِيين حد (الوأد) وحد (الحموية) يأتي زمن الأنوثة معلّةًا في فراغ الثقافة وذلك منذ أن حرصت التقافة على حجب أجزاء من اللغة عن الانثى فالمر أة لاتسمع و لاتحضر الاّ في حيّز محدود من المجال اللغوي"(^)، فيما للرجل لغة غير محدودة وغير مقنّة وتملي شر ائطها على المرأة اذا احتازت جزءاً يسيراً منها، مثلما يجري 
تصنيف الانوثة وتتميطها وفقاً لما تفعله الواحدة من النساء، بمعنى أن فكرة الأنوثة أساساً

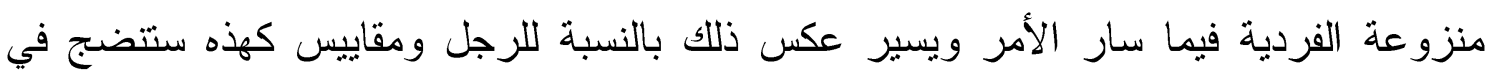

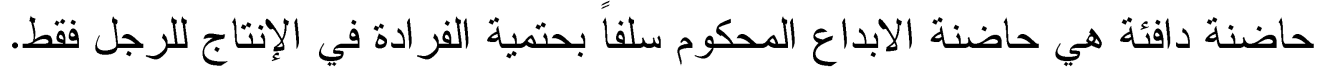

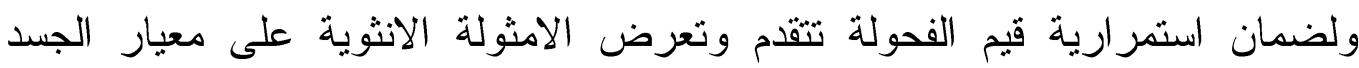

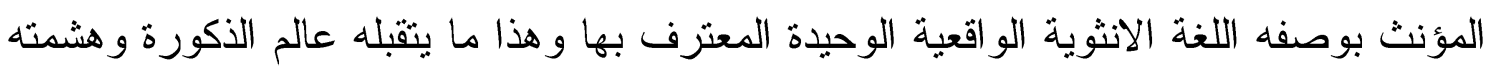

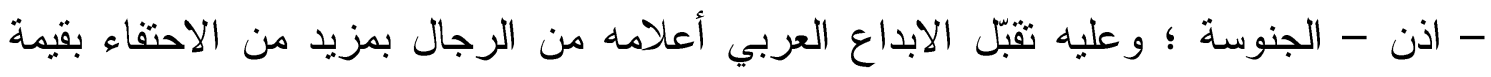

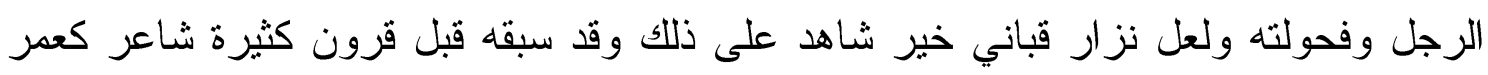

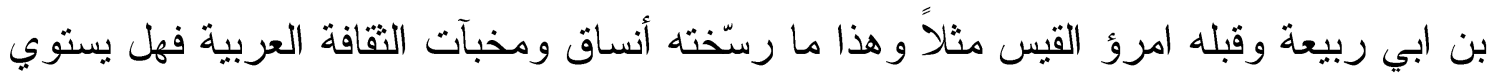

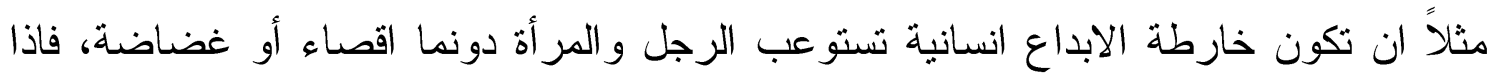

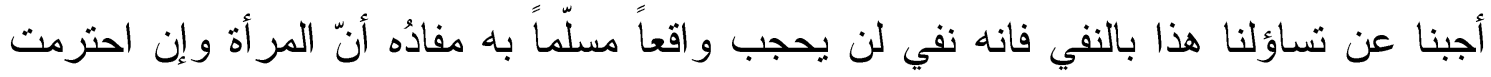
ار ادة الثوابت لكنها حافظت على تفعيل سجالية ذكر / انثى وشاهدها في ذلك انها سجّالت اسمها/

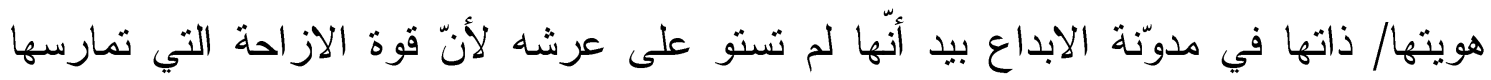

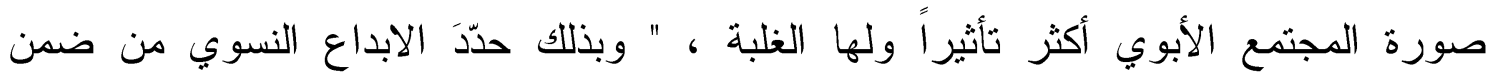

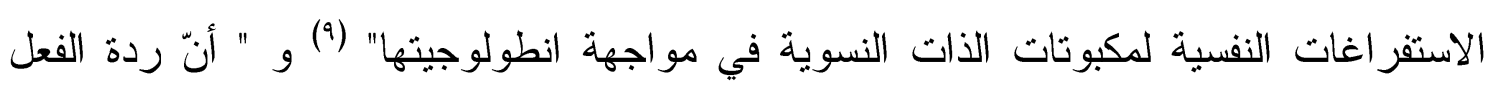

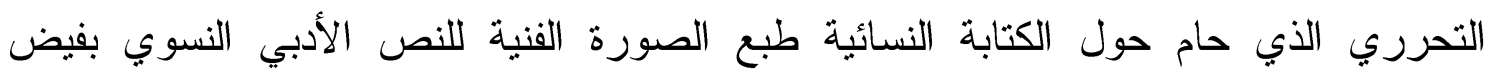

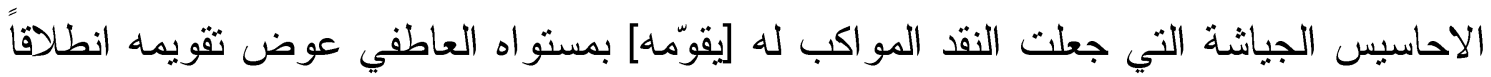

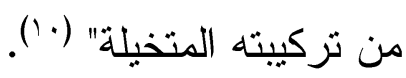
لكن ابداع المرأة الذي يكون مناط هويتها الانثوية وضغوط التنميط الذي عمد إلى تقزيم

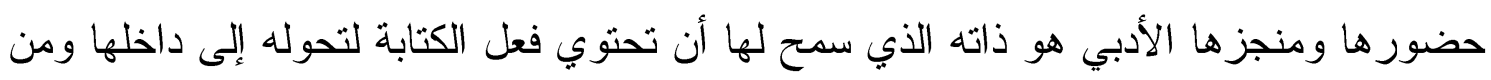

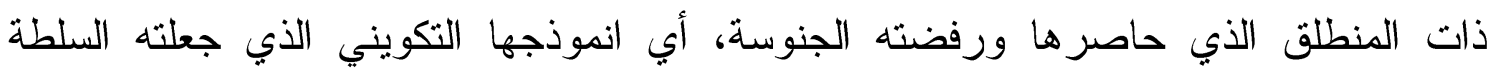

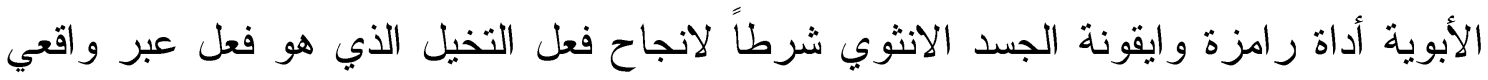

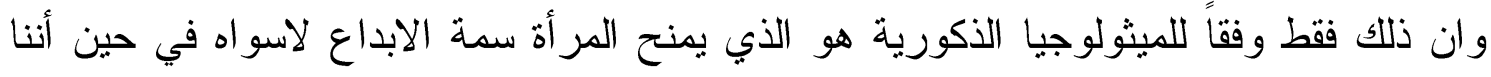

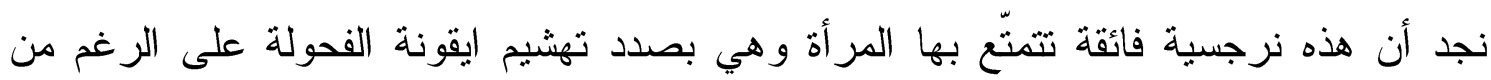

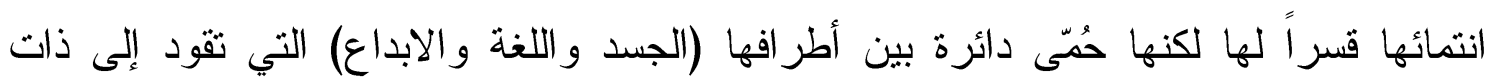

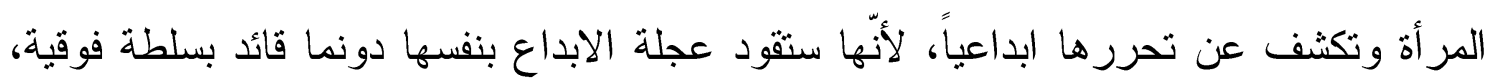

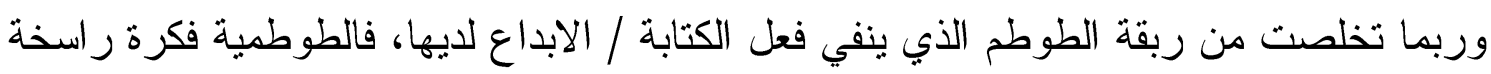

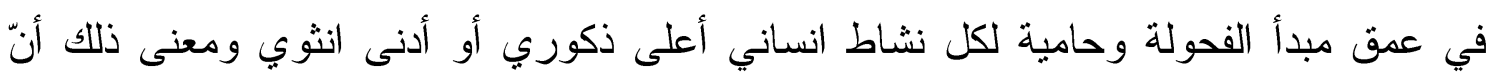

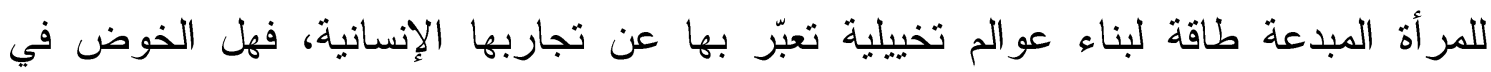


تفاصيلها يستوجب اجابة عن مدى قدرة الرجل في ولوج تلك العو الم - مثلاً - وفهم اشكاليتها الكبرى المخبأة في جسد الانثى ورموزه. نتتاول هنا جانباً آخر غير الطوطية ورفي وفي حدود تساؤل بسيط عن علاقة جدلية / تقليدية

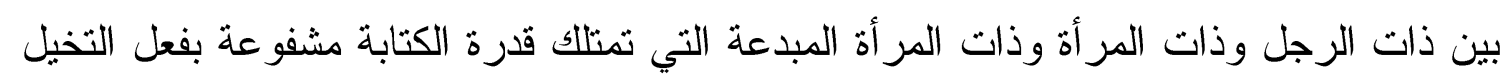

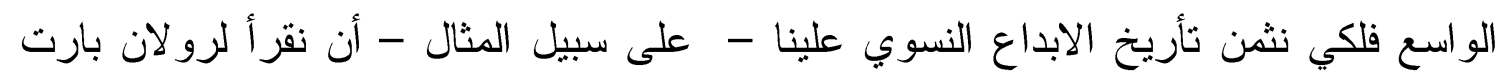

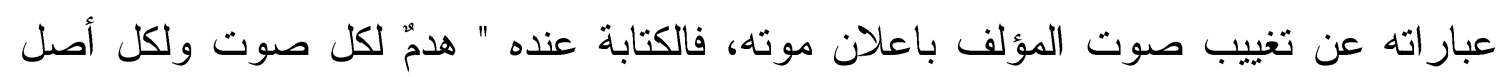

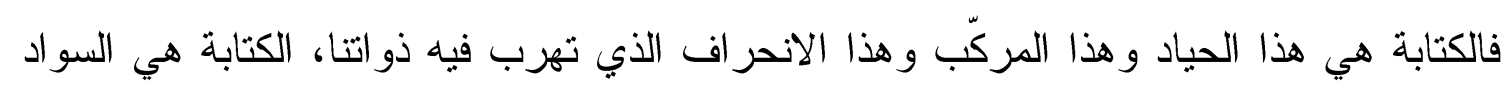

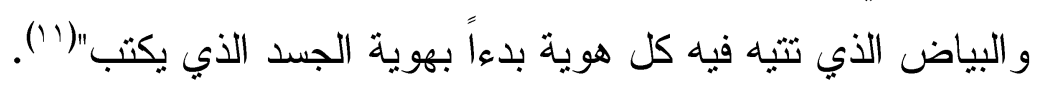

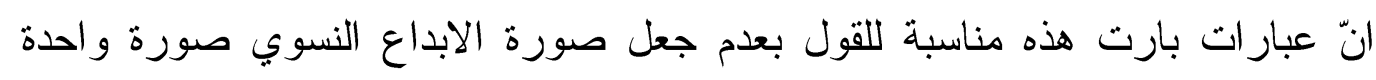

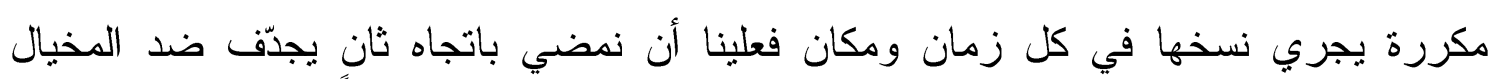

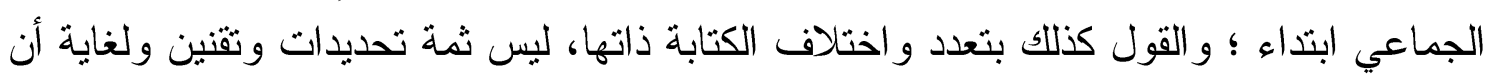

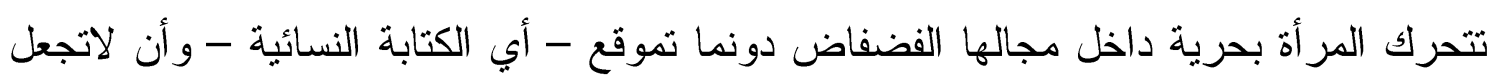

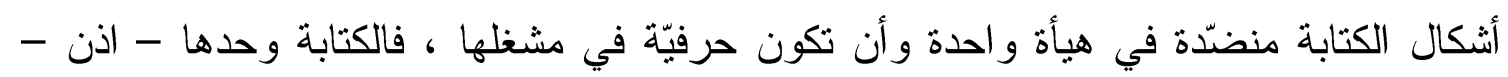

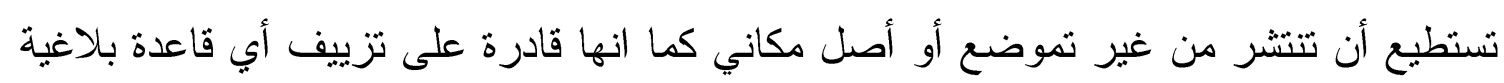

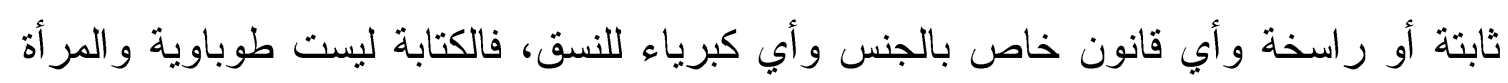

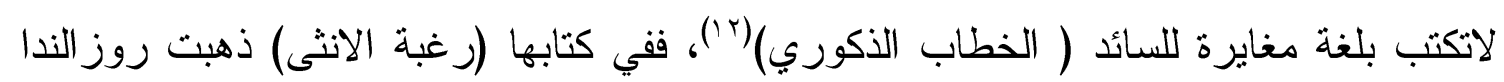

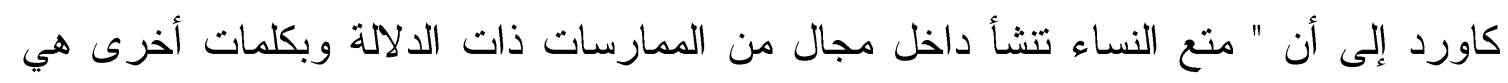

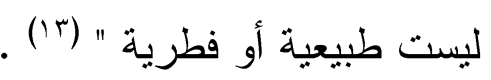
وقد قدّمت لينداهتشيون لذلك من منظور ما بعد حداثي إذ تحركت بالطبع ضمن افقه

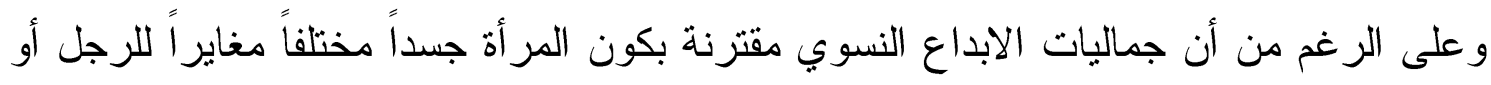

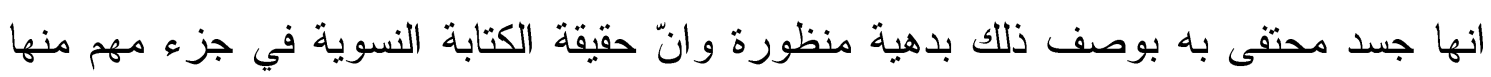

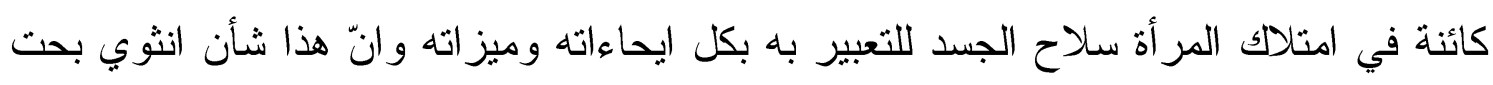

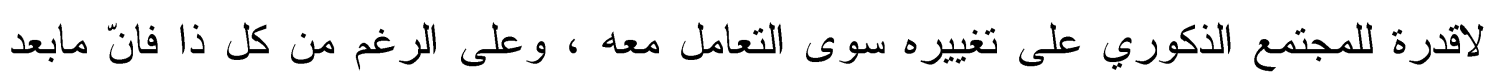

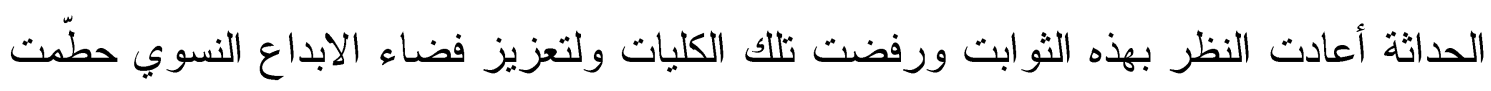

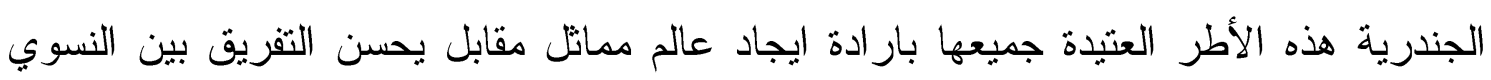

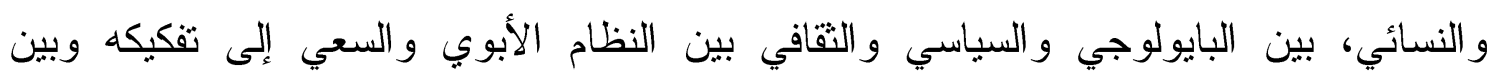

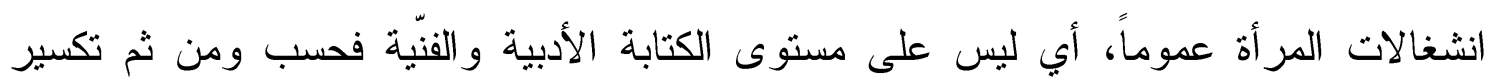

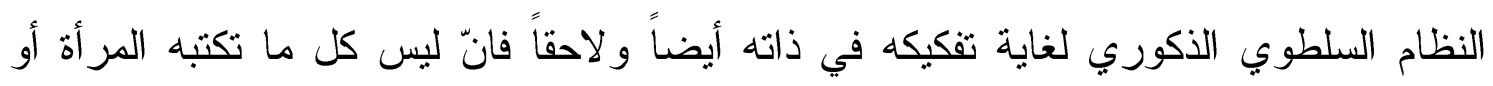


النساء -جمعاً - يُعد أدباً نسوياً ورفض التسليم بانّ ما تكتبه انمّا هو خلاصة تجارب انثوية

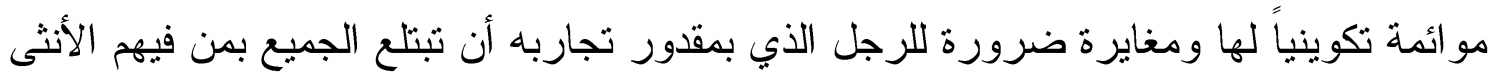
من موقع أدنى، و امتداداً لذلك نلاحظ صنيع فرجينيا وولف في رواية (الغرفة) ففي عملها المهح

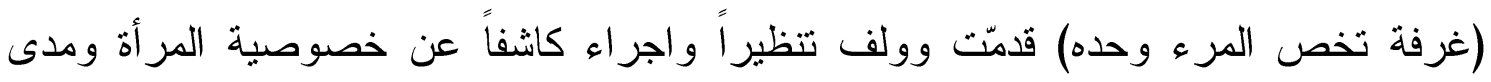
حاجتها لاثبات تفردّها بالبحث عن دوافع اقصائها و إبعادها تحث سطوة المجتمع البطرياريكي فتكون الغرفة مع الثخصيات النسوية التي تضمها ردة فعل تجاه الظروف الاجتماعية و التقافية التي قمعت قدرة المرأة واسهامتها في الكتابة وكتابة تأريخها و امتلاك لغة تجادل بها وولف

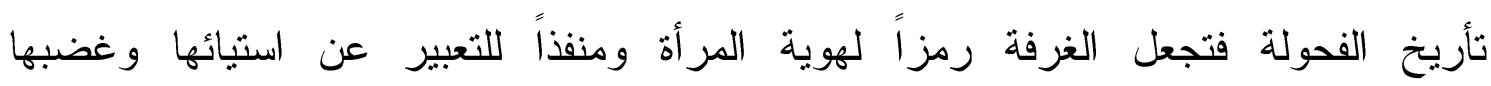
وخصوصيتها كامنة في مفارقة أنّ الغرفة ذات الجدران الأربعة هي العالم الاوسع للمرأة و هويتها أيضاً التي ترفض عن طريقها عادات مجتمعها المسيئة لها. و الغرفة بعد ذلك هي قر اءة سوسيولوجية لحال المر أة في مجتمع الكاتبة الر اغب بالتمرد على المنظومة البايولوجية القاضية بمبدأ التمايز ولابد من وجود اختلافات حيوية ومهمة بين أدب الرجال وأدب النساء وهذا جزء مهر من اعتناء النقد النسوي منذ طرحت الناقدة الأمريكية ايلين شوالتز عام 9 19 كتابها (نحو بلاغة نسوية) فاستدارت حركة تاريخ النقد نحو الابداع النسوي كتابة وقر اعة، ما تكتبه المر أة، ما ثقر أه ، ما يكتبه الرجل عنها وكل ما هو ملائم لقضايا المرأة وأشكال ما تتتج من ثقافة خاصة بها، وهكذا فعوالم المرأة الداخلية - قيد اهتمام النقد النسوي - تعني - أيضاً - مقدرة المر أة على تتاول مختلف المشكلات و الموضو عات الاجتماعية و الثقافية والأخلاقية وسواها من القضايا الإنسانية التي يكشف عنها ببر اعة دائمة أدب الرجال ولقصد اخراج فلسفات أنثوية مهمة من مثل العلاقة بين الرجل و المر أة بعد اضاءتها بكشّافات تجلو عتمتها تأريخياً أو توازن بين كفتي فاحصيها، أي الرجل والمرأة وعدم الاكتفاء بمنظور سلطوي مهيمن عليها وهذا من شأنه قلب المواضعات التي رسّخها المجتمع وقيدّ بها حرية لغة المر أة. و المر أة عند تحليل دو افع تحررها كائن نرجسي يتمحور حول ذاته وتتطابق صورتها مع لغتها وما ترغب فيه، فهي تكتب بجسدها مالا يستطيع النظام الرمزي الذكوري تفكيكه أو فهمه و المر أة تحس المرأة عن بعيد ويظل مناط نرجسيتها المتضخمة ردة فعل على الواقع القهري الذي يحكمه الرجل وان كتابتها الكاشفة لذاتها ورغائبها ما هي إلاّ آلية للدفاع داخل علاقات

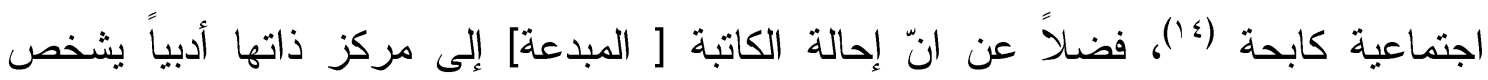
التمركز الو اقعي لأنويّها في المجتمع التقليدي منذ الانفلات من الوأد الجاهلي إلى الاشكال 
المعاصرة للو أد" (10) ، وهكذا تكون نصوصها الابداعية تزموميثر ايقبس الشؤون الانثوية الآتية تتالياً ( اللذة والألم - لغة الجسد - الانيموس: نظرية يونغ في احتواء كل أنثى على شيء من

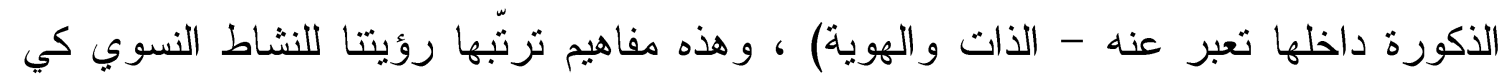
تحقق فرادة على مستوى الابداع الأبي خاصة ؛ ولميعة عباس عمارة شأنها ملائم لما نريد لأنها دأبت على تفسير ذاتها وتقديمها مقروعة مكشوفة لمن يفتش عن أسباب تفردها وخصوصية تجربتها الشعرية، فنصوصها مليئة بحقيقة الأنثى المعترفة بكل شيء، بعاطفتها تجاه الرجل

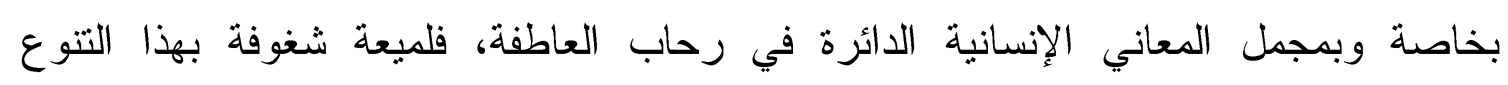
الوجداني والانساني وأردفت شغفها هذا بلغة سهلة لاصعوبة فيها لكنها اسلوبياً لغة شعرية مكتملة الأدو ات.

\section{r- الأنثوية : وهمر الجنوسة وترنيمة الشاعرة:}

واذ يظهر لنا أن مصطلح النقد النسوي محك دقيق لاختبار تفوق الذات الانثوية المبدعة

فانّ اختيارنا للميعة عباس عمارة جاء تصديقاً لتفسير أثر المبدعة ولنقف على ما يترشح - هنا - من طاقة ابداعية ذات ميسم نسوي ممهور بجنس كاتبته، ولميعة اسم لايثثر اشكالية في جدلية القبول و الرفض أو لمزيد من الدقة لايثير اشكالا من أي نوع لأنها مقروءة انسانياً و ابداعياً، و على الرغم من انها تذكرُ و احدة من أصحاب الريادة الشعرية في كتابة قصيدة التفعيلة إلاً أنها بعدت بأدبها عن الاخول في مناطق شعرية شائكة وهو ابتعاد عفوي غير مقصود، فضلاً عن انها قدّمت منجزها بهدوء ينمّ حين يُقر أ عن وجهة نظر خاصة وانثوية لكنها مواكبة لمرحلتها

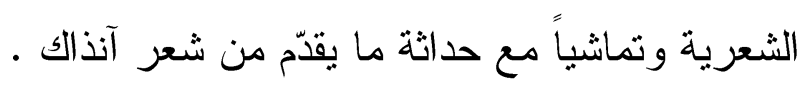

ومّرت نتاجاتها بسلاسة في ميدان الشعر العربي بعامة ، لذلك استقرت لميعة فوق

أعر اف أية أزمات مهما كانت أطرافها ومن دون أن يكون لها دخل فيها، فاستطاعت بذلك الحفاظ على منهجها في الكتابة الشعرية من غير أن تسعى لمز احمة مقو لات التذكير والتانيث أو تقصد لبلورة اتجاه نسوي مخالف لما ير اد له في الشعر أو الأدب عامة، الأمر الذي ربما كان سيربك خطّها ويقولبه لاحقاً، فكانت معفوّة بفضل انشغالها بتقديم اسمها من خوض غمار التصنيف، كما ان نصها لم ترتفع نسب عطائه بتغيير أو تعديل أو إضافة أو حذف وما ارتقى في سلم الثعرية إلى حدّ اثارة المفاجآت وبلورة التغاير فبقي يراوح في مناطقها الأولى ليستقر تماماً إلى منظومة انثوية تداولية مشدودة إلى ذاتها بقوة وقادرة على مغنطة كون شعري خطابي ذاتي تتموج فيه حركة الوجدان بين معاني ذاتية تصور معاناة الثاعرة وتقلّب عاطفتها وقناعاتها 
تجاه الأشياء في الحياة، الأمر الذي يجعلنا قبالة اهتمامات انثوية عامة وعائمة جمالياً وفنباً لأنها

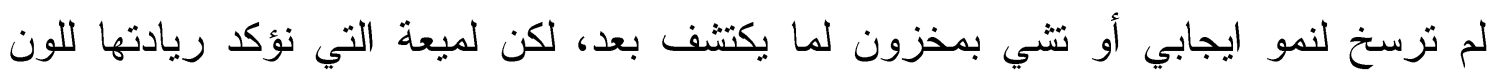

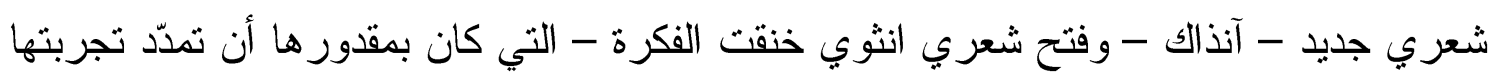

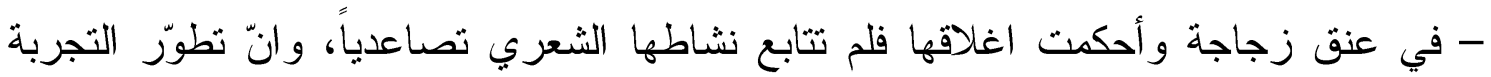
النصية للثاعرة أو السعي لاثر ائها لم يسر باتجاه تطور حتمي فبقيت قصيدتها مظللة بغمامة

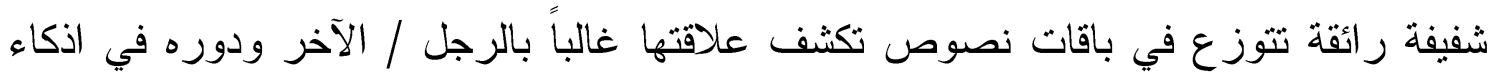

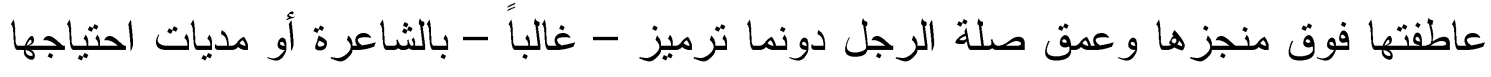

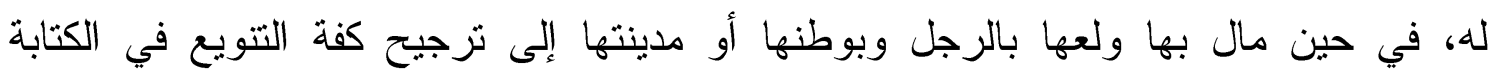
الشعرية فنظت لميعة مجموعة جيدة من القصائد الثعبية المكتوبة باللهجة العراقية المحلية

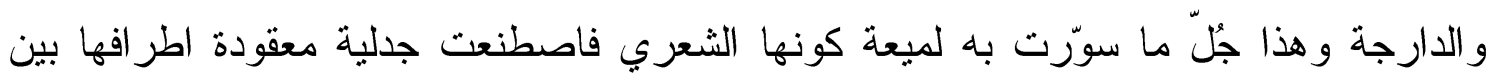

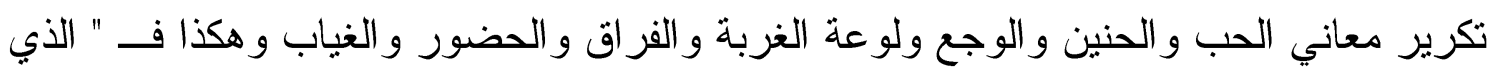

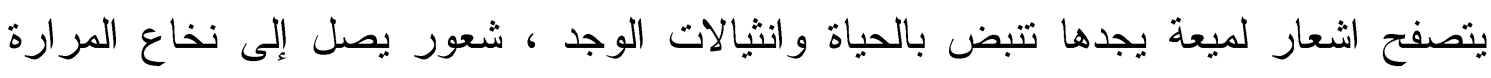

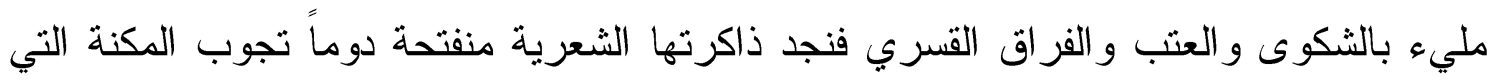
غادرتها" (17).

وتأخذ لغة لميعة الثعرية نصاعة وبريقاً جميلاً عندما تلامس عو الم الثاعرة الداخلية

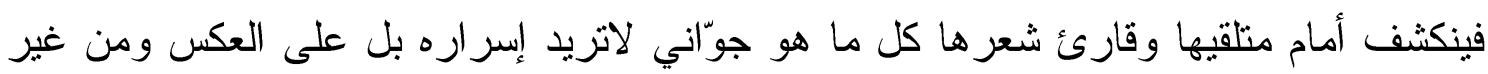

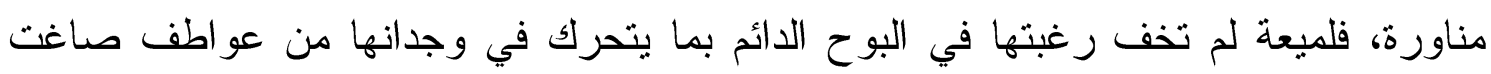

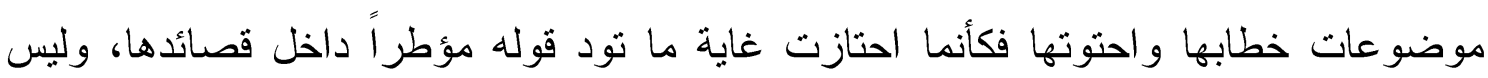

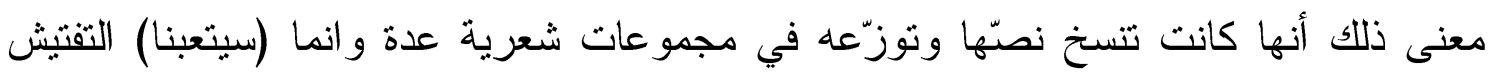

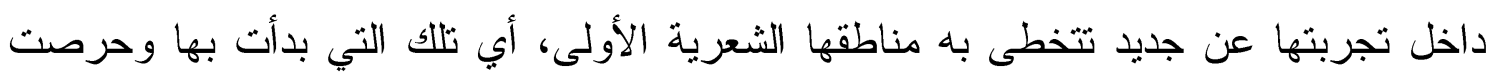

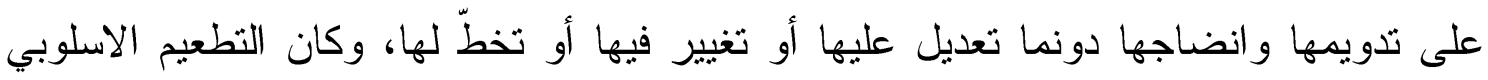
الابرز لديها ماثلاً في النص الثعري الثعبي فقد برعت فيه وأدّت باجادة على نحو بماندانل نظمها قصيدتها الفصحى.

وتحترف لغة لميعة الثعرية ما نسميّه (الانثوية) فكرة الانثوية أو موضوعتها التي تتطق

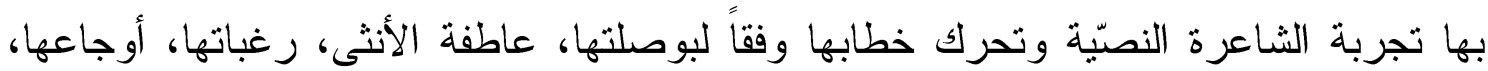

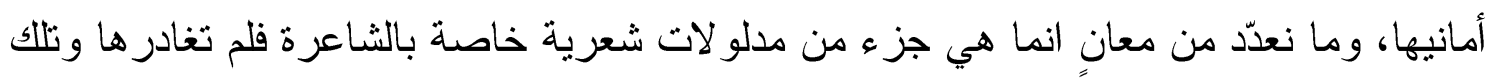

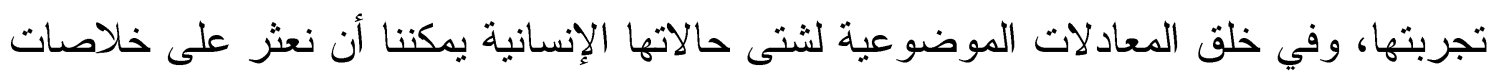

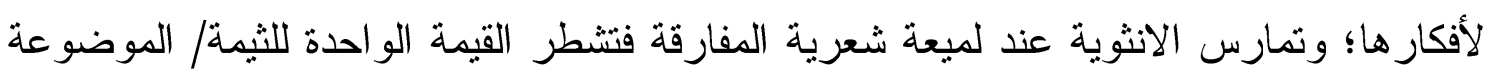


الو احدة بين طرفيها، فاحتفاؤها بذاتها - مثلاً - لايلغي أو يهيمن على جزئه النقيض أي حاجتها

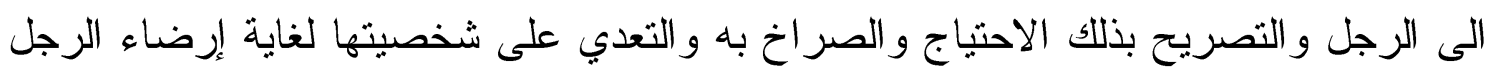

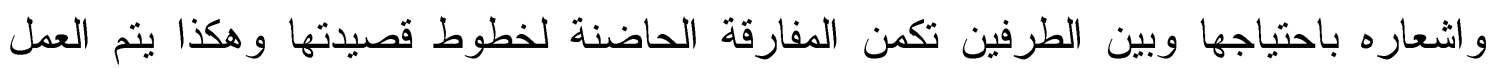

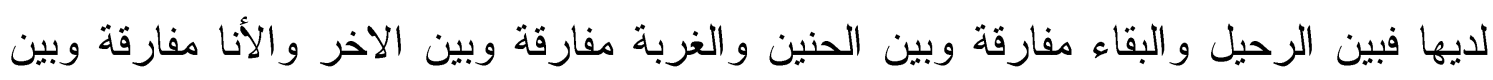

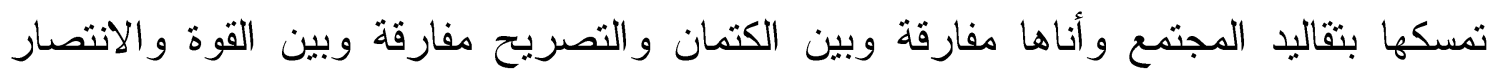

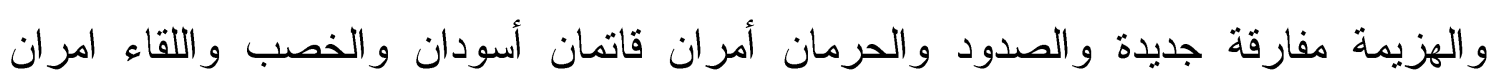
ايجابيان أخضر اند.

وتتتوع تثانات النص الانثوي عند لميعة فلديها مخاطب بسير حضوراً بجوار الأنا

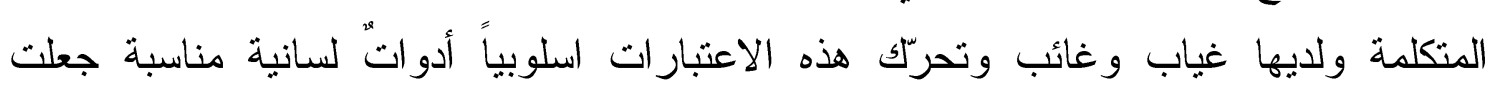

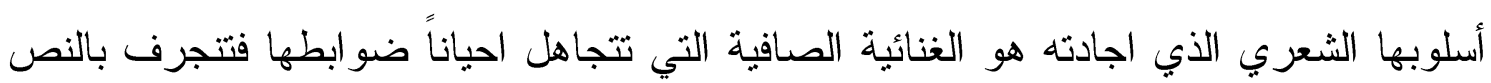

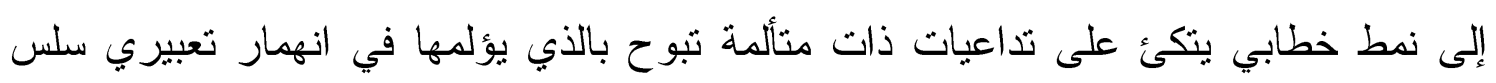

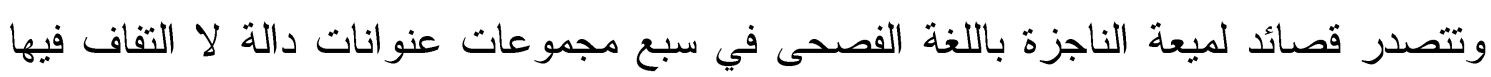

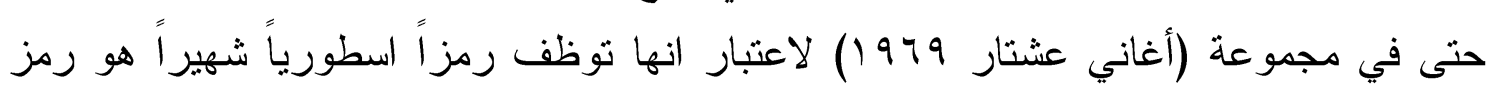

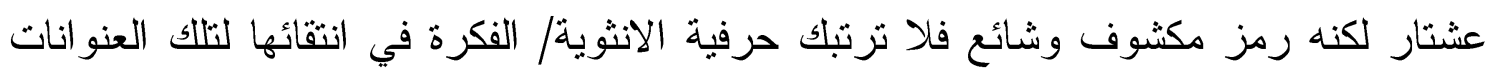

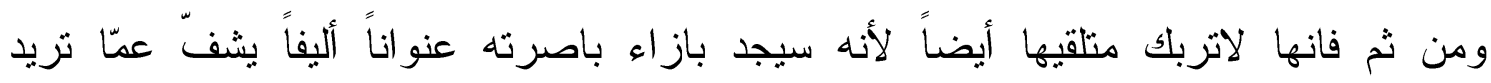

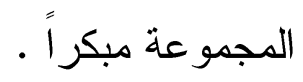

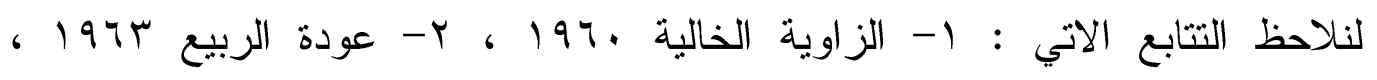

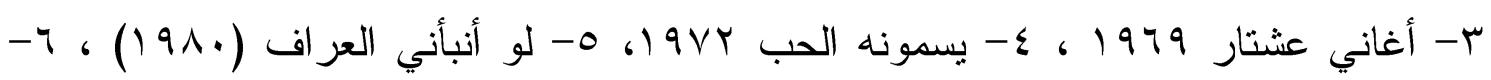

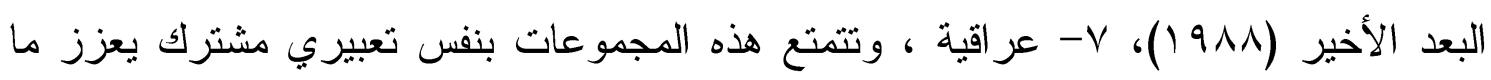

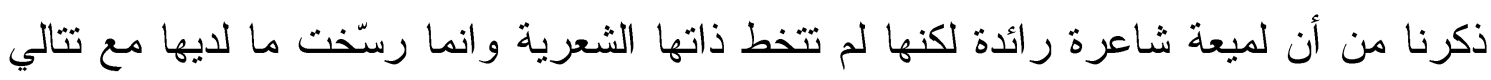
نتاجاتها وهذا أمر يشي بتميز من نوع خاص لأن نسبة مقروئية شعر ها بقيت مستقرة و عالية

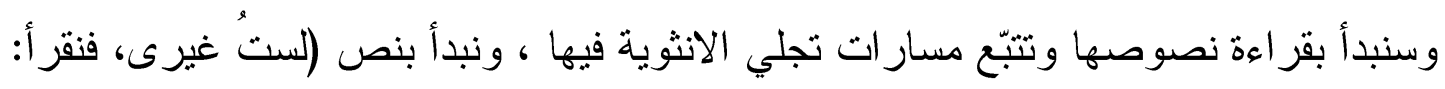

سيدي طقلي

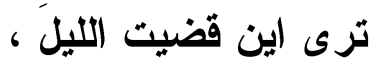

ليَّ الأحدِ ؟ ؟

مُشنقلاً بالثنغل؟

أم بين ذراعيَ أغيد؟

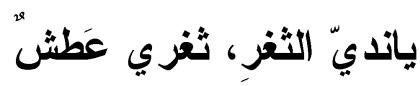




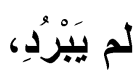

كم تمنيتك بالأمس ...

فما نعمت عيني،

ولاضمّت يلدي،

أنا خوف مزمنه تجهُهُ

وحقول مُرّةٌ لم تحصدِ

يائساً ترجعُ من وصلي

فانْ قرّب الشوق وساداً

\section{أُبعد}

تبدأ الثاعرة قصبدتها برصّ ما يحدث لها في علاقتها بمخاطب واحد دوماً هو الرجل ويبدو أنه الموضوع الأهم لديها وهنا تتفرغ لسؤاله لا بقصد انتظار اجابة بل لتدير الحديث باتجاه ذاتها، انها تسأله بغاية مساءلة رغبتها فيه أو عاطفتها تجاهه بدليل انها تظهر جانب الرفض و التمنّع الذي تفترضه هي لأنّها في حقبقة الأمر نزيد عكس ذلك تماماً و هذا جزء أنثوي خالص يشفعه كسر بنسق آخر ضمن ذات الأسطر التي دوّناها لأنها إذ تلعب دور الغاضبة المتمنعة الر افضة فانهّا بذلك تمعن في تعرية ضعفها وفضح احتياجها لهذا الرجل ولكنها تحاول الامساك بعصب الكبرياء والاعتداد بالذات و الضغط على هذا العصب لتتبيهه فتسقط في احدى مفارقاتها المعنوية فتضعُ بين الرغبة والعدول عنها كبرياء زائفاً يشي بتفعيل مشغل الانثوية بوصف الأخيرة خلاصة تضمّ اليها تفاصيل النص وما يحويه أو يقدمه من علاقات متنوعة، و تشكل عتبة النص (لست غيرى) درجة استباقية لهذا المشغل الانثوي لأنّ ما يُفيدُ به الموضوع الشعري داخل القصيدة يؤكد عكس ذلك ويرسّخ إجراء المفارقة، أنها تقصد العكس تماماً في بساطة ظاهرة و غنائية عاطفية رحبة. و هذا النص - تحديداً - فيه تشيؤُ وحس كبير، فيه رسم لحالة تعيشها المتكلمة وصور شعرية حسيّة موحية ترتقي أسطح الجمل وتتو الى في دفقة مجزأة، اعتناؤها الوحيد التعبير عن وحنيل الألم الذي يحيط ذات الشاعرة بطرائق حسية ملموسة وتعمل في النص هذا عدة وحدات لسانية وللسبب ذاته ، فما دمنا نتحدث عن دفقة شعورية منثالة فانها بحاجة إلى اشباع لغوي ، لذلك ونك يتحول الخطاب داخل النص بين ضمائر عدة يربطها خيط واحد تجمعه كفّ الشاعرة المتألمة و لاشيء افضل من هذا تقدمه عن فكرتها في النص. 
تتحرك الفكرة الكلية (غيرة امرأة) في الأسطر المسجلة مباشرة مع السطر الأول

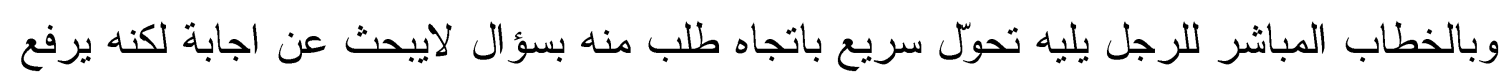

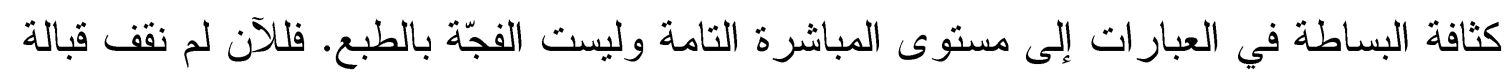

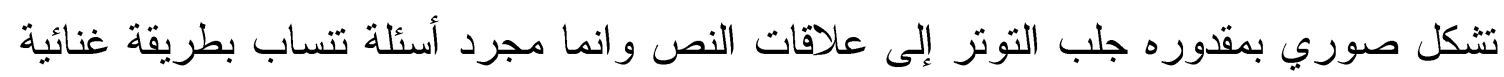

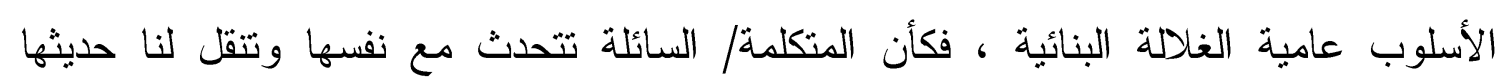

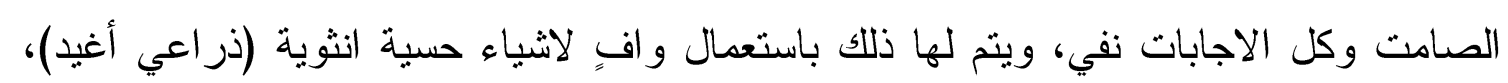

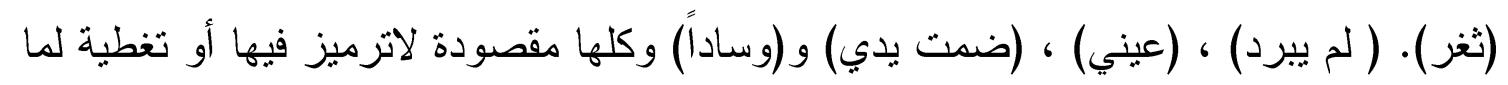

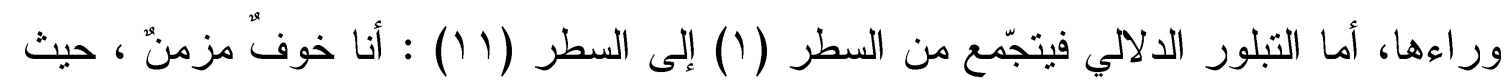

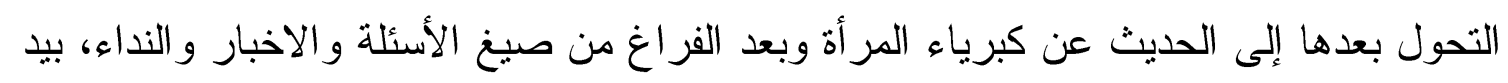

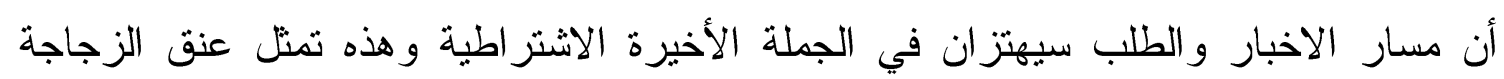

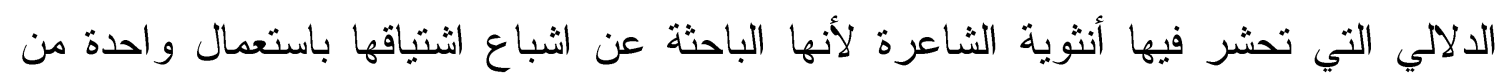

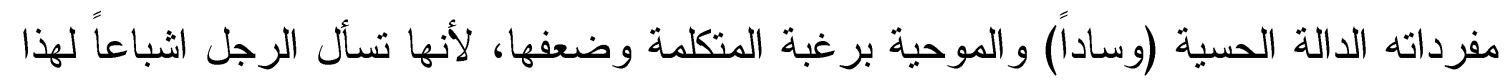

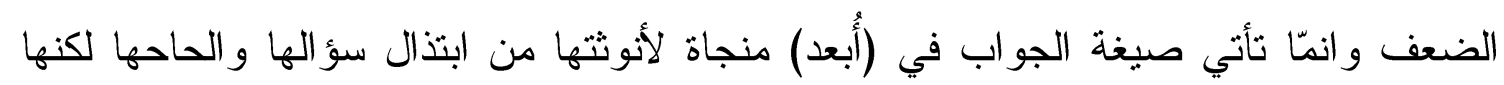

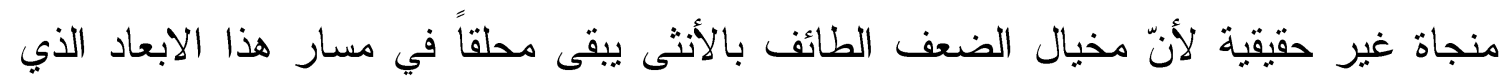
تدّعيه المتكلمة/ الثاعرة. لنلحظ الأسطر القادمة من النص:

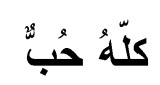

فصدري صدرها

وبها مني لينُ المسندِ

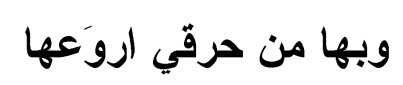

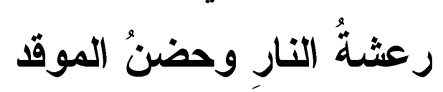

$$
\text { ليس حبي الطوقَ }
$$

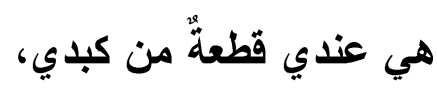

يفيدنا هنا أن نعود إلى العلاقة الجدلية التي تهزُ مجتمعاتتا بعد أن ننحي الجنوسة و العلاقة

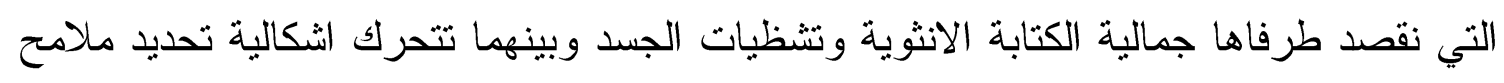

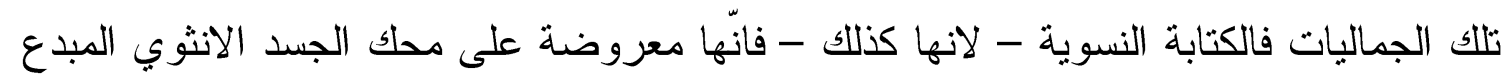
و انّها تحصدُ جمالياتها بالنظر إلى أن المر أة جسد مختلف ناطق بمالا يحسنه الرجل، وأمرٌ آخر 


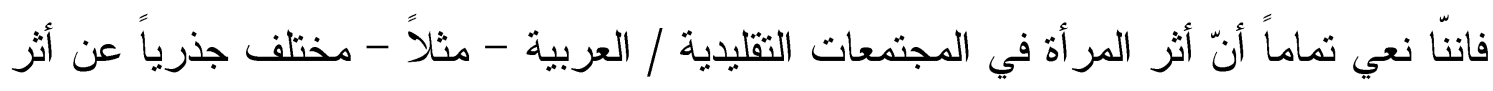

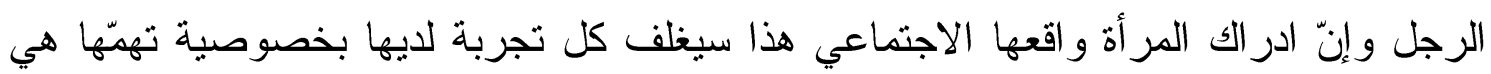

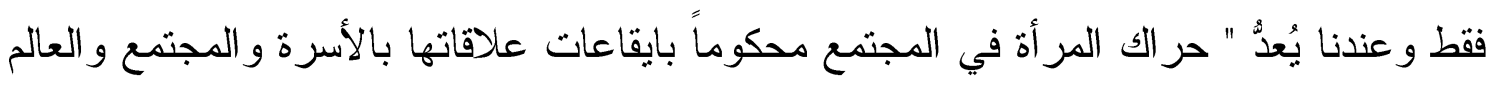

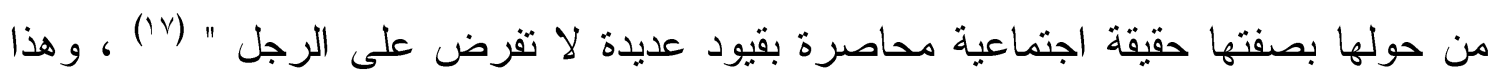

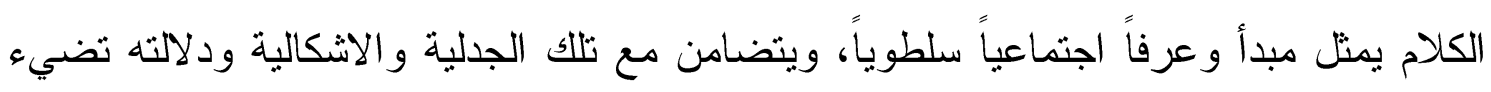

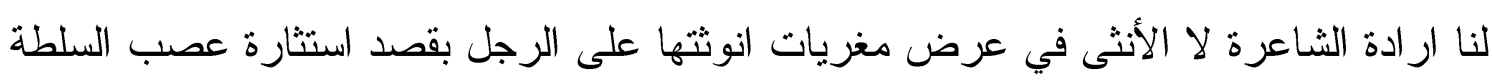

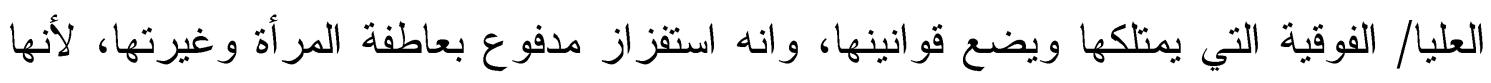

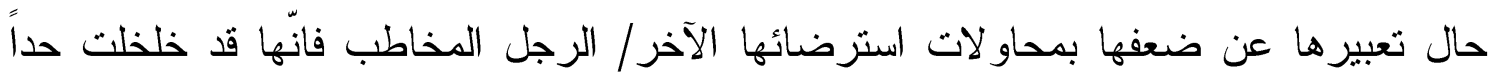
ضرورياً من أسوار الجندرية.

وما يجري انتها استفزت رغبتها تجاهه حتى تعتصر اقصاها بين مفارقة دلالية، ما تدّعيه

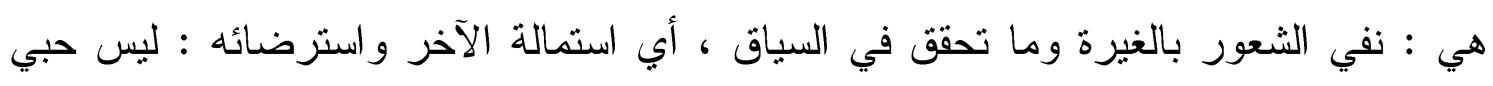
الطوق. أي انّها سيّرت الأمر بطريقة معكوسة ليبلغ غايته مع مفردة الفداء في جملة (افدي عنقاً)

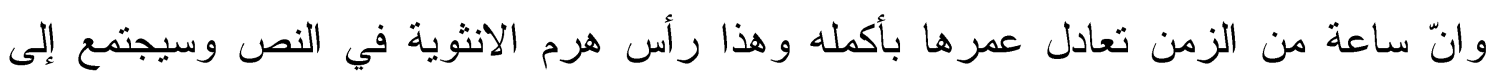

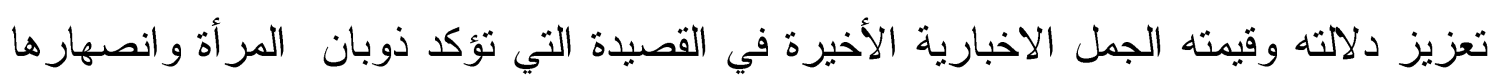
في الرجل مع أية قيمة كان يمثلها، فتخاطبه أخيراً: عشْ كما شئت فر اثشاً، بلبلاً، نحلةً أشرك معي

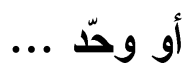

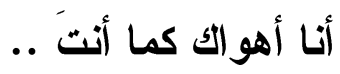
استرْحْ

\section{لاتبادرني بعذرٍ في غدٍ.}

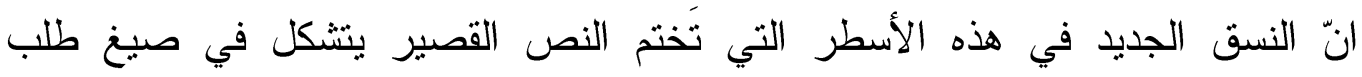
مقصودة وهذا النسق المعقود بأفعال الأمر و الصادر من ذات مبتهلة الألى ذات ذات أعلى و أثوى منها

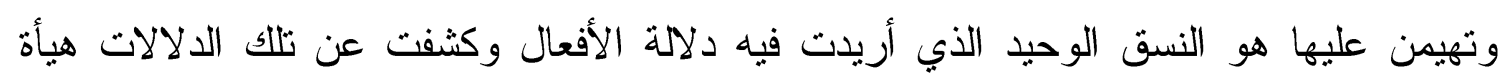

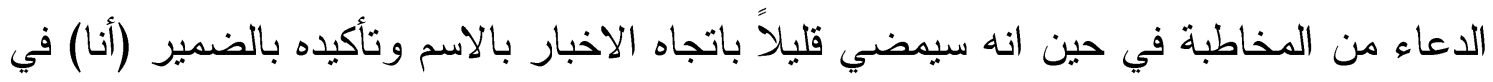

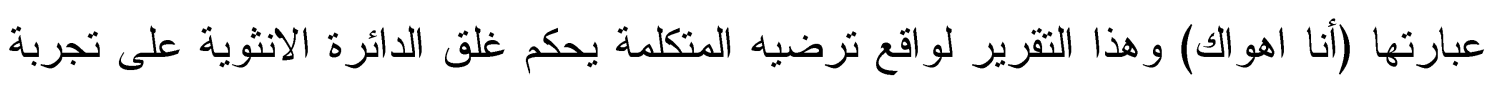

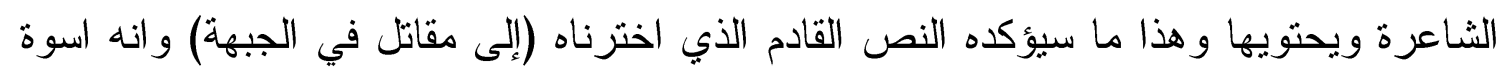


بسابقه وجميع نصوص الثاعرة نص غنائي سهل لاتعرج فيه ويحمل في عبار اته حكاية حلوة بسيطة عن علاقة المر أة بالغائب/ الرجل و انتظار ها له.

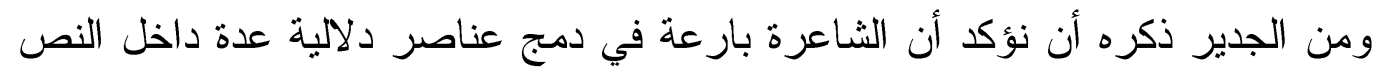

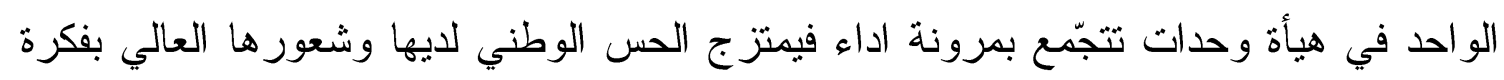

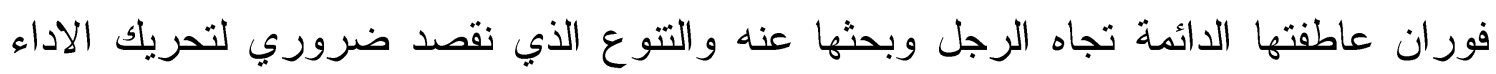

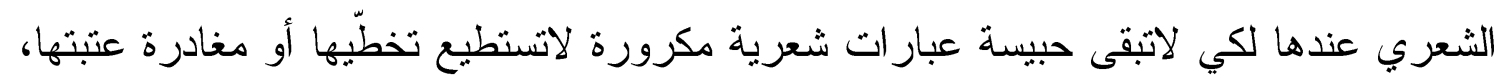

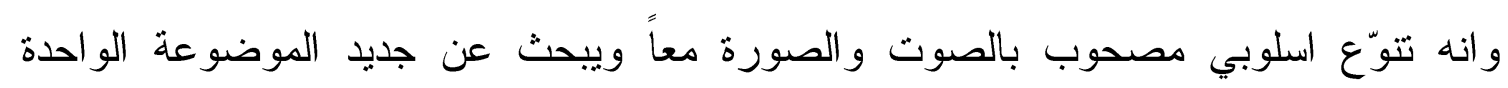

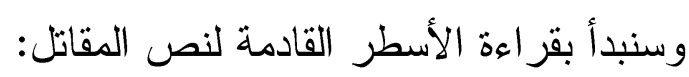

$$
\begin{aligned}
& \text { وأيقظني البردُ في أُخريات لِيالي الخريف } \\
& \text { تملمت } \\
& \text { راحت ذراعي تجسنُ مكاتلكَ } \\
& \text { عادت تجمّع حولي دثاري الخفيف دوني }
\end{aligned}
$$

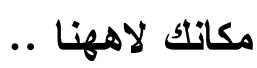

$$
\begin{aligned}
& \text { قد تذكرّتُ }
\end{aligned}
$$

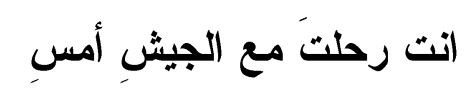

يمثل هذا النص اطلالة أخرى لأنساق الحس العاملة بدقة داخل نص لميعة إذ أنّها تتوزع

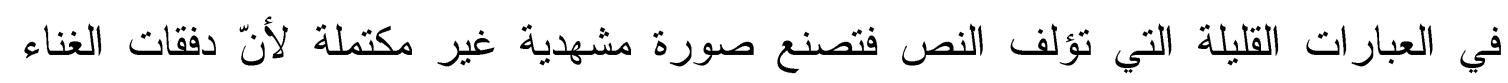

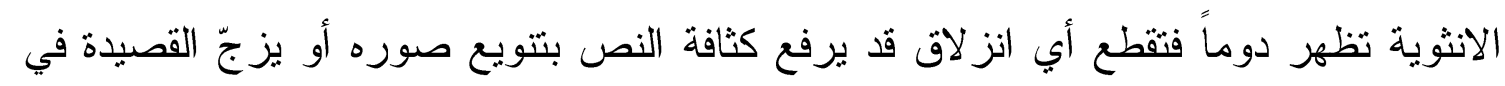

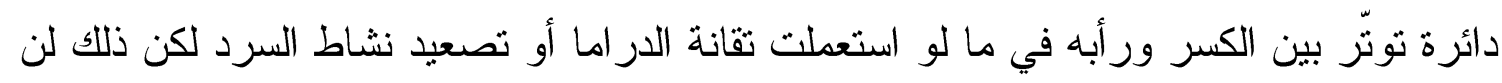

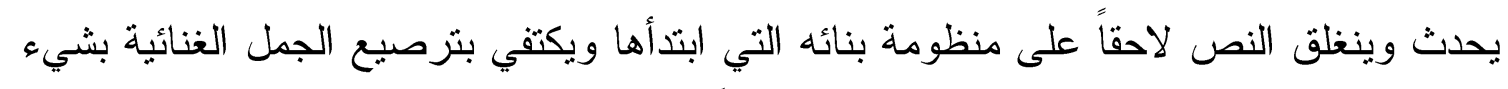

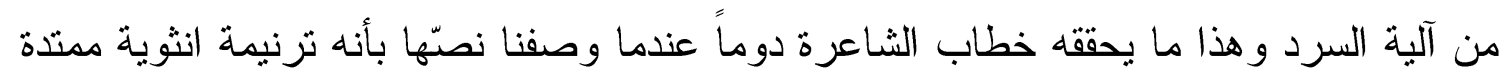

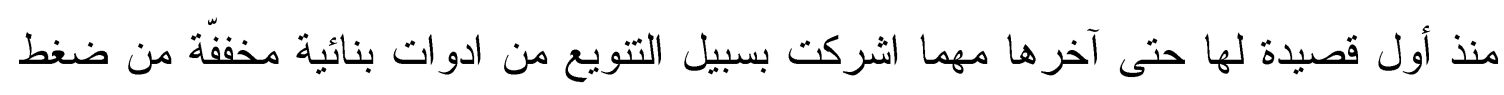

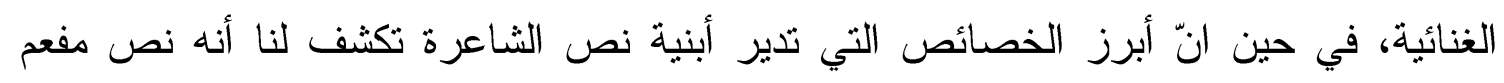

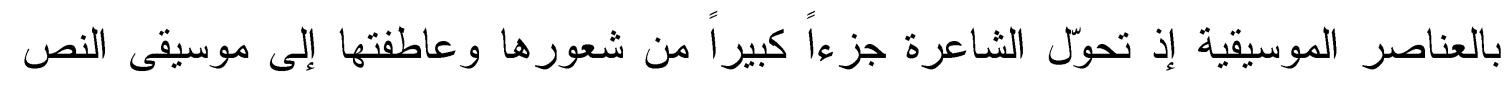

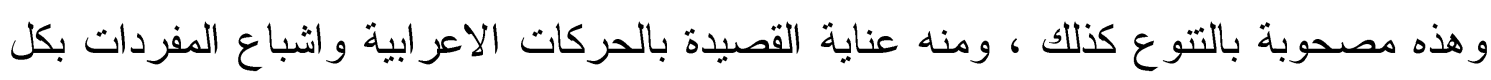
حركة مع رسمها تبعاً لقوة الغناء وارتفاعه في القصيدة.

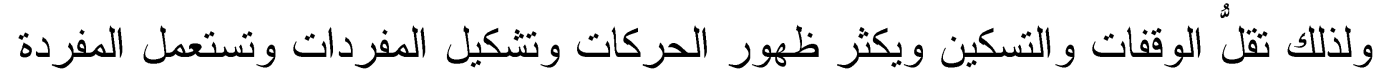

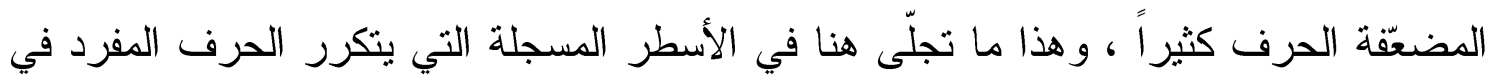


ست مفردات منها بين اسم وفعل (ليالي / تلملدت / تجس"/ تجمّع / خفيفه/ ههنا/ تذكرت) وكل

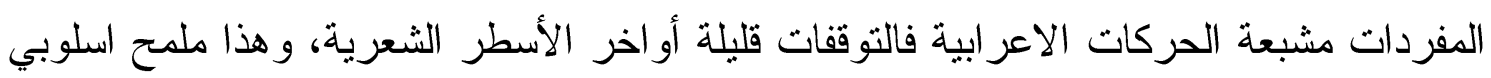
كامل ومشترك صوتي لساني دلالي، لانه مسؤول عن رفد الصور الثعرية بما بلائم الثيمة

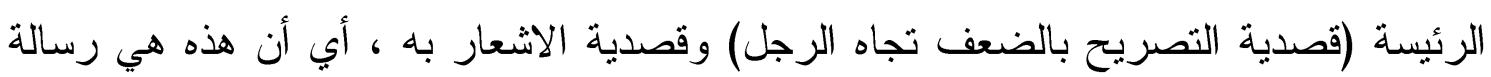

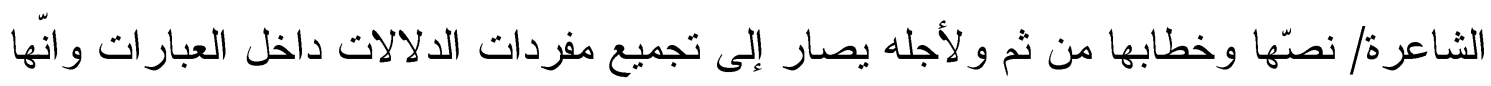

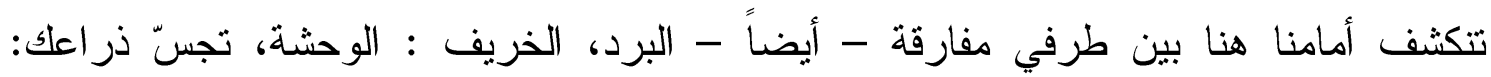

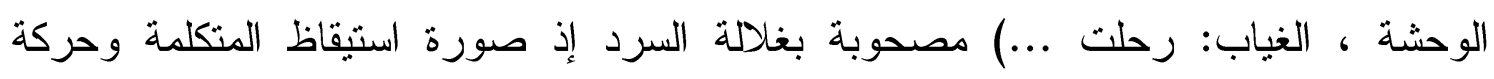

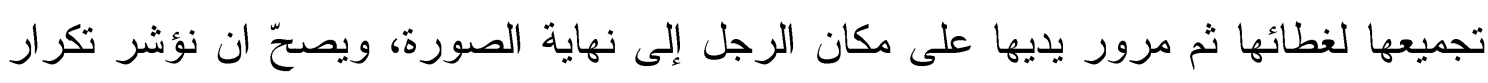

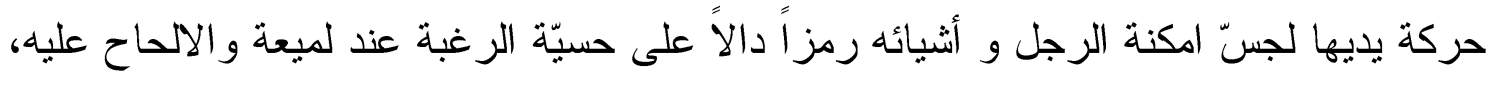

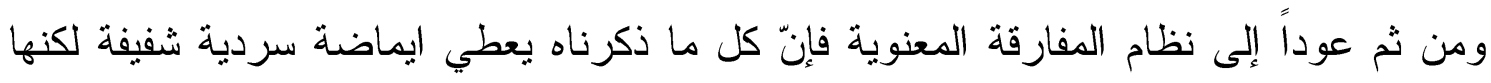

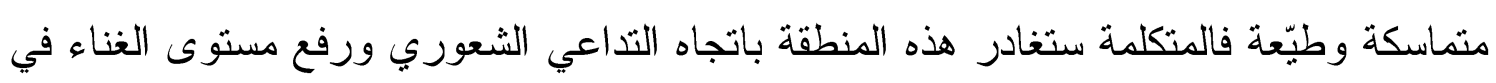
الأسطر اللاحقة للنص. وليس من أماكن شاغرة ننتظر" ملأها بل عبار ات تتواتر في معطياتها الدلالية بطر ائق

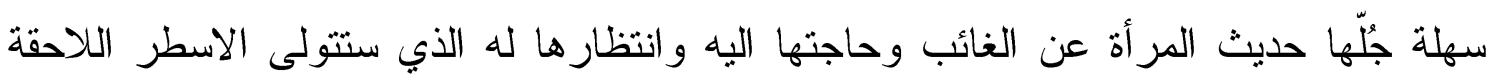

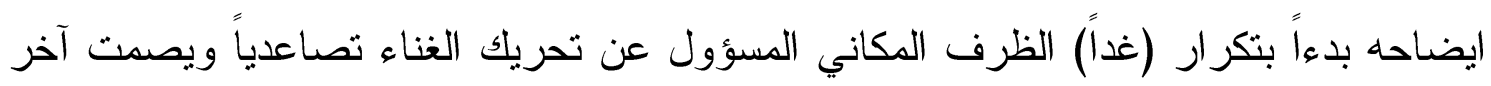

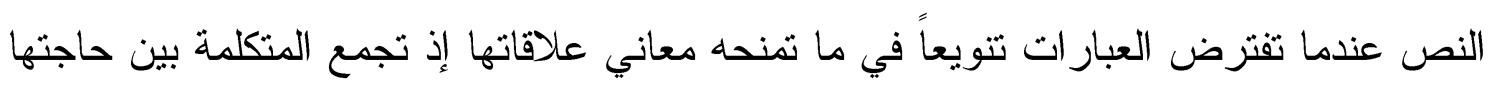

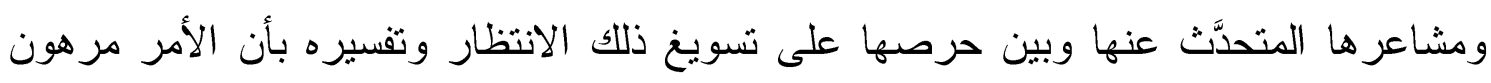
ببطولة رجل وغياب مقاتل، و هذا موضوع شعري مؤسلب عند لميعة إذ تمثل عاطفتها الإنسانية

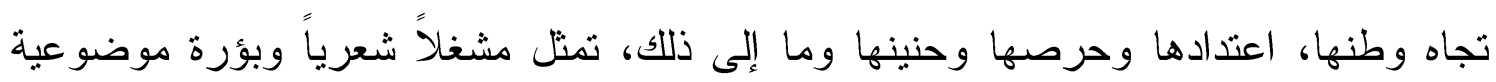

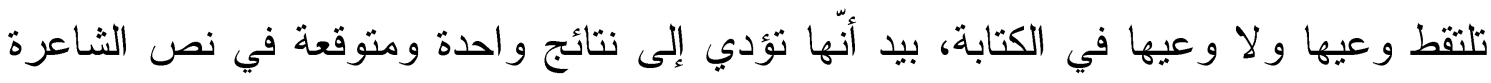

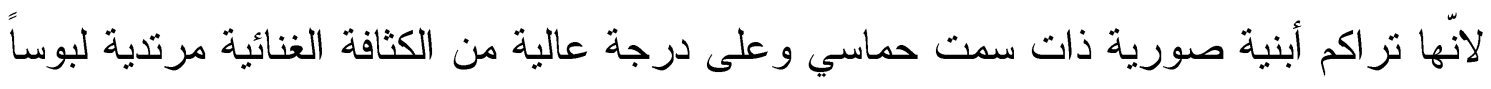

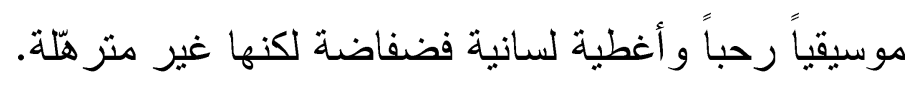

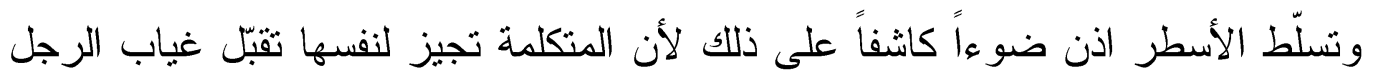

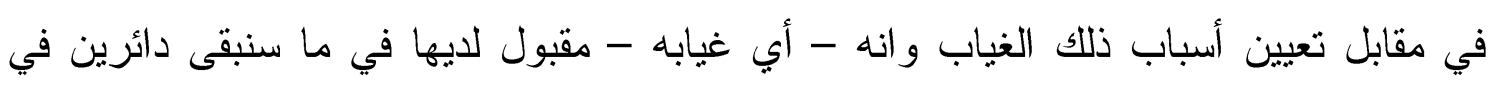
بؤرة الأسلبة الانثوية التي تحترفها نصوص لميعة، وسنقر أ المزيد من النص: غذاً سأعانق فيك البطولة غقرت لبردِ ليالي الخريف ووحشة تلكك الليالي الطويلة 


\section{غداً سالمّع نجماتك الثامخات

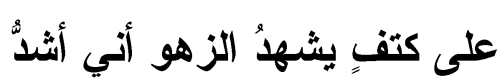 \\ عليها. \\ وتحسدني مئة امرأة}

تعمل هذه الأسطر على تدويم المشهد الانثوي كما تطلّ استدارة ضمير المخاطبة تبعاً لتوجيه الظرف الزماني (غداً) بين الرجل ومجموعة النسوة وبنتوع ضمائري بستبدل الضمائر

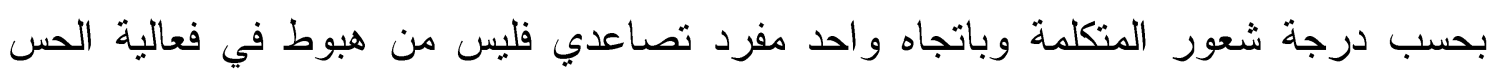

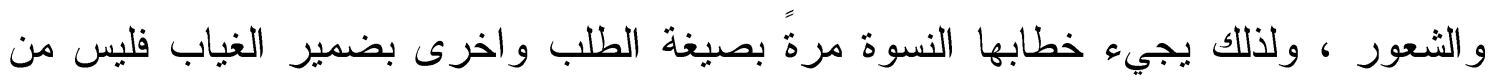

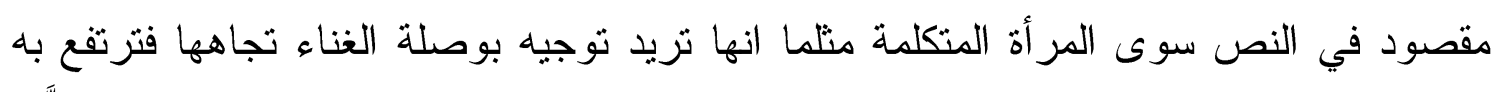

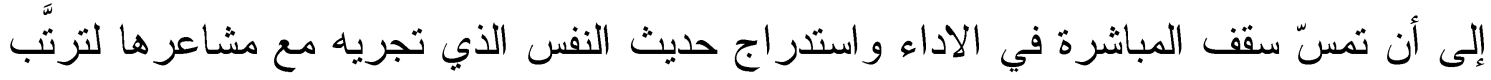

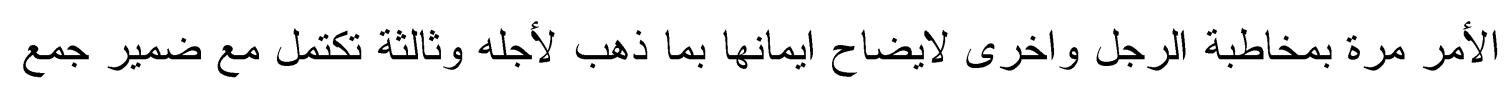

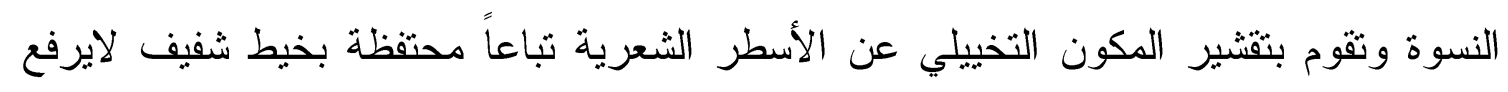
من مستوى التصوير ويصنع صوره.

وبين العودة بالظفر للرجل ومن ثم سؤال النسوة عن حسدهّن ستستقر درجة الانثوية

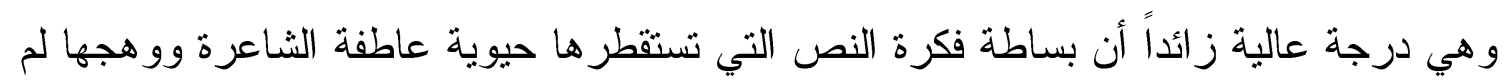

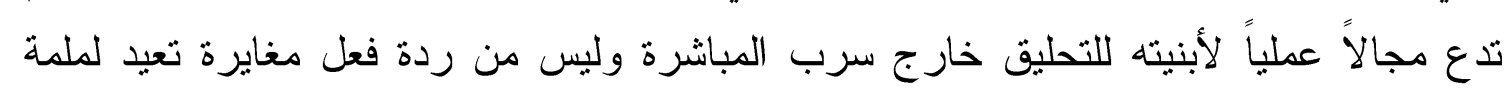

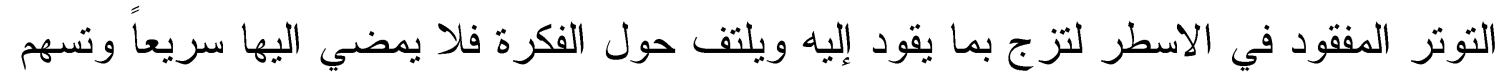

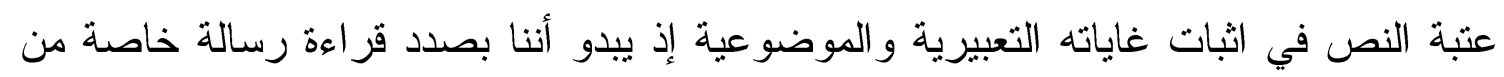

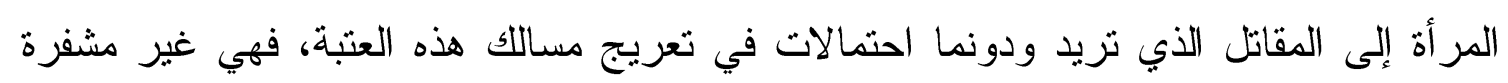

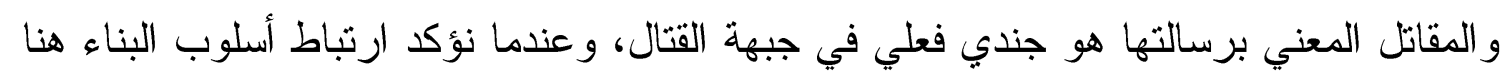

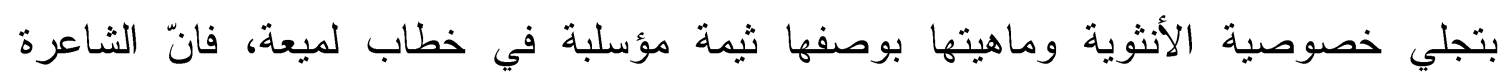

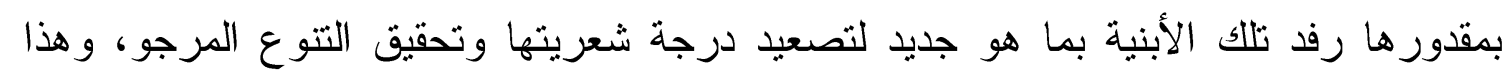

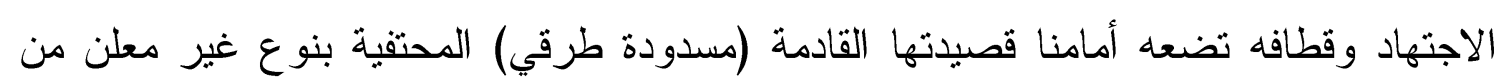
التجديد لكنه، حاصل فعلاً وو اقع في الوقت ذاته ضمن مسار اتهات اسلوبية نص الثاعرة، فلنقر أ:-

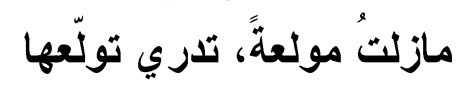

مشدودة للك من شعري ومن هُدُبي

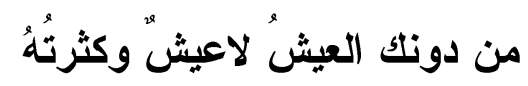

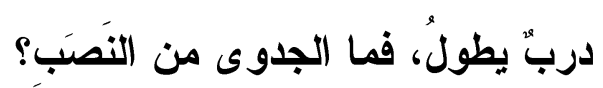




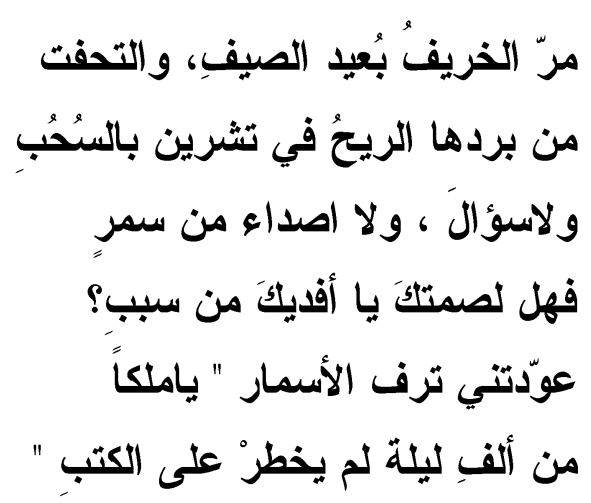

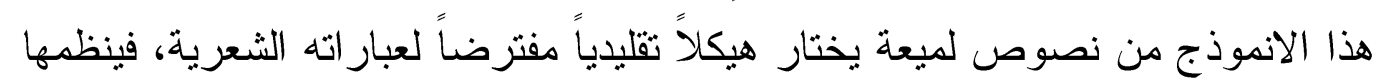
في قالب الصدر و العجز وان لم يعلن رسمها فوق الصفحة عن ذلك ويختار نرتيباً عمودياً بهيأة

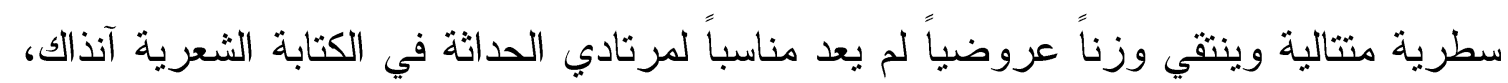

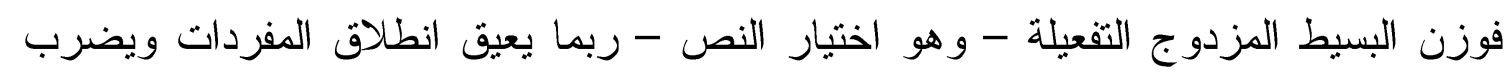

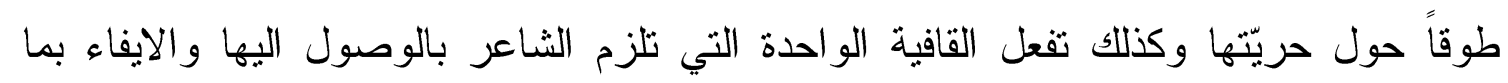

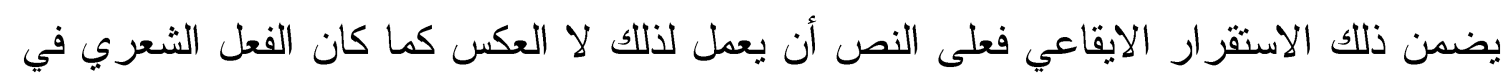

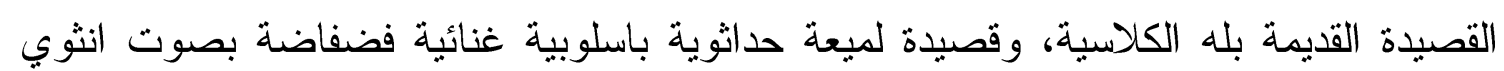
مترنم بما لديه، بما يشغله، ولبوس التقليد سيقدم رؤية اتفاق مقصود بين الثاعرة تجاه اختبارها لئها

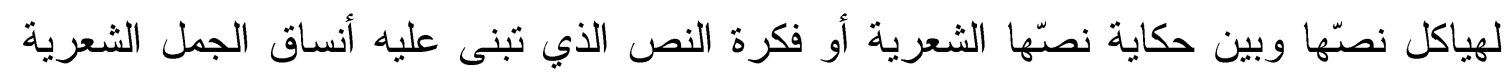

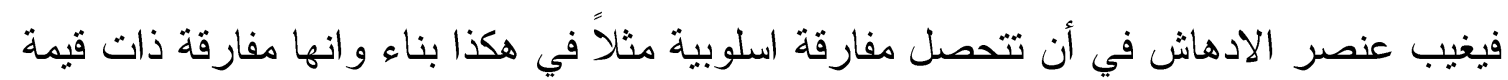

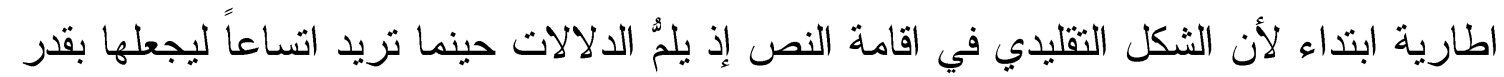

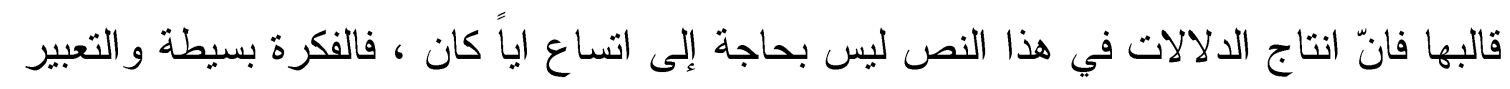

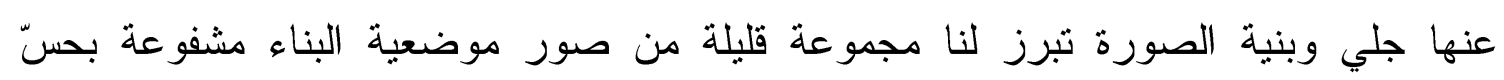
تعبيري مأخوذ بعاطفة المتكلمة فحسب.

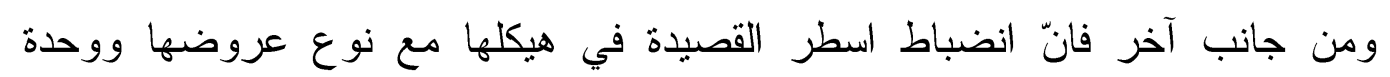

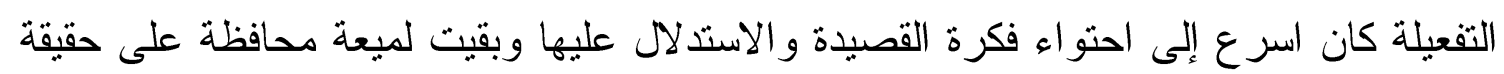

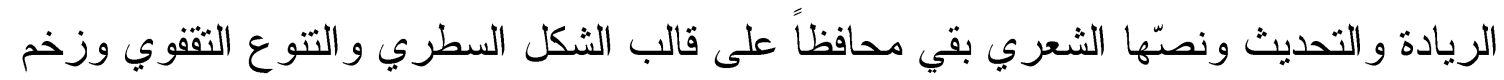

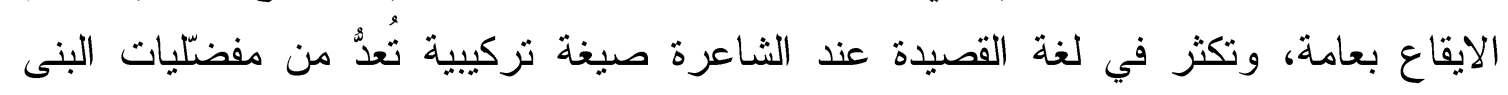

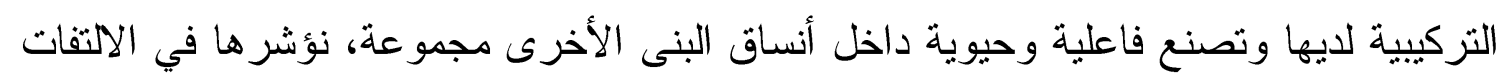

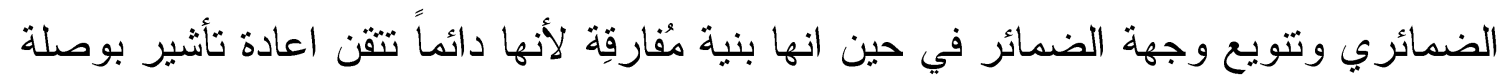

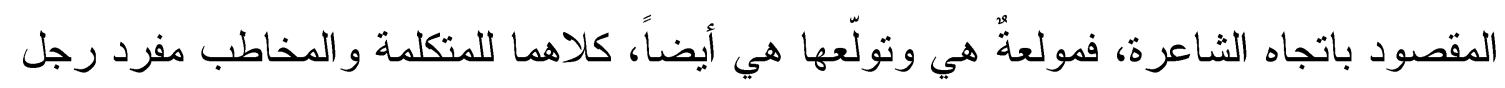

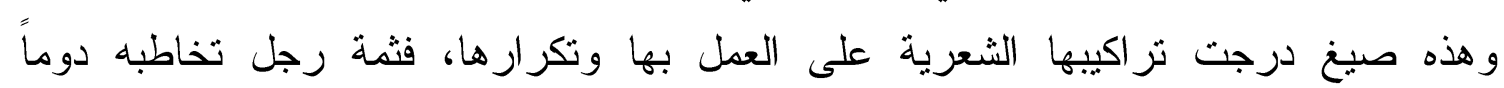


و استمرارية زمانية تبدأ مع مطلع القصيدة وترسيّخ مبكراً فكرة الانثوية عن طريق أطر اف عدة

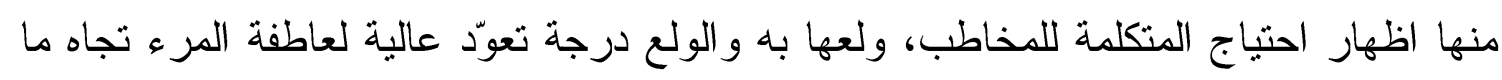

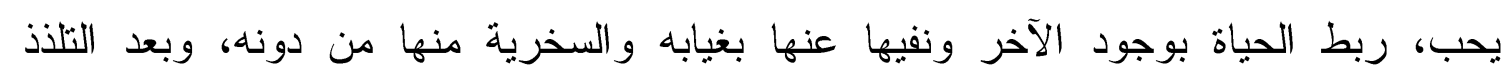

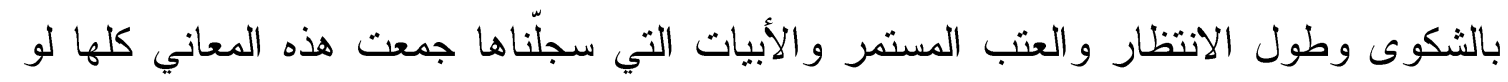

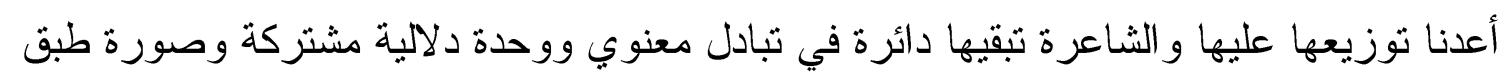

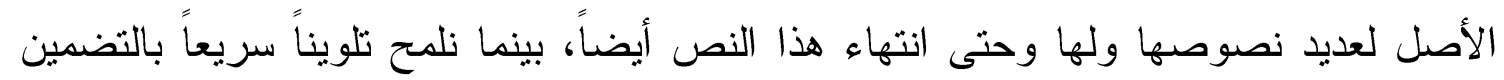

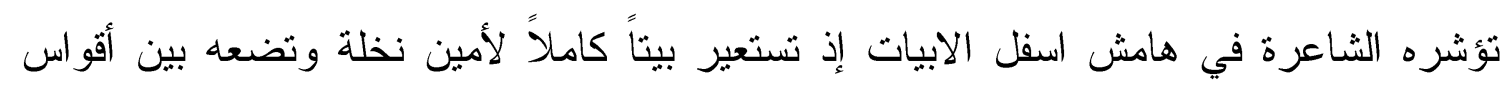

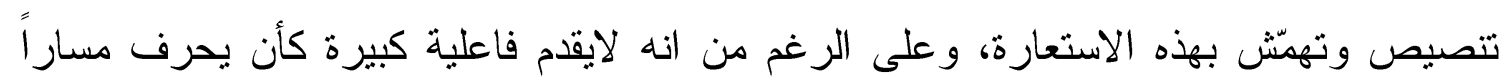

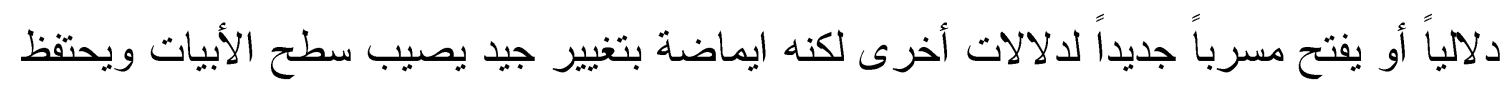

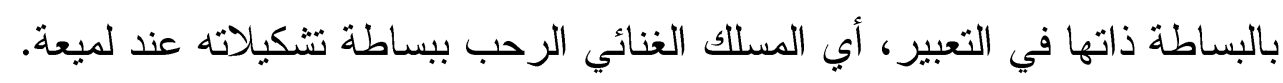

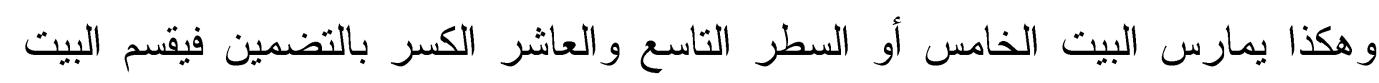

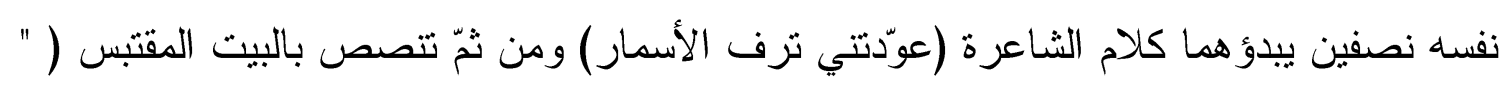

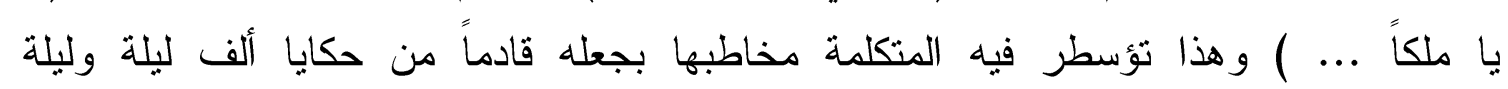

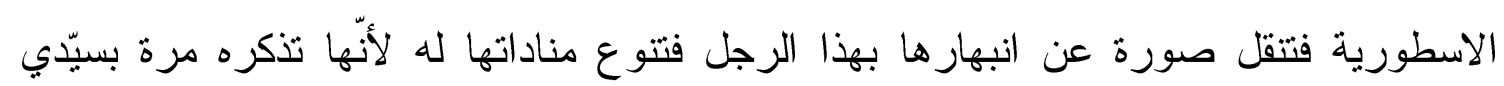
وأخرى بأبي وثالثة بملك ورابعة بحبيبي وفي ذلك تكريس للالالة فقط، فلا زيادة على المشغل

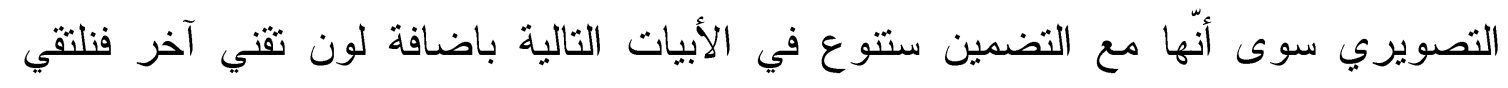

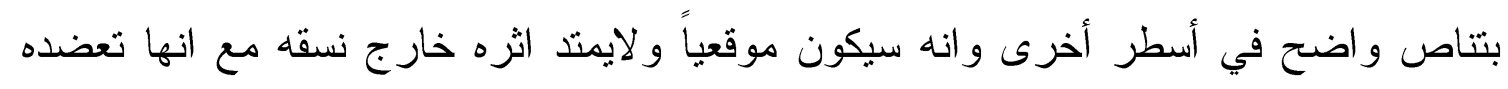

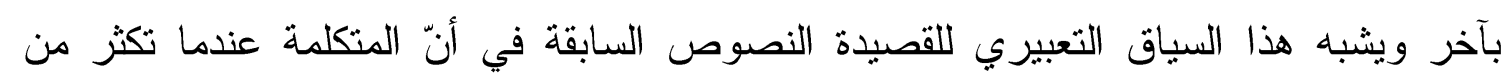

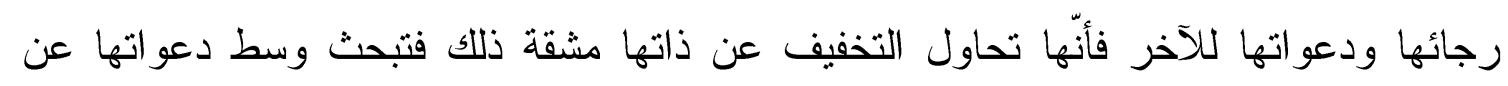
هويتها الذاتية في حين انها تتصهرُ في ذات الرجل بعامة مع تلانك التأشيرات الذاتية.

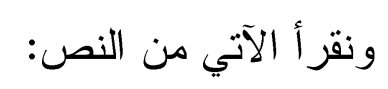

ارار مستوحش الأظلال ياسعفاً ما كان أزهاك بي في موسم الرطب! بمن تعوضضني يا من تقطعني

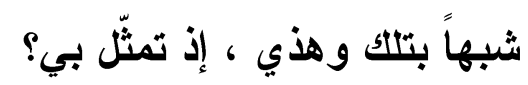

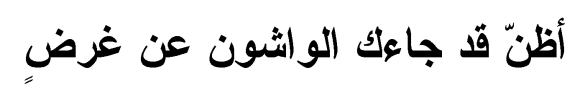

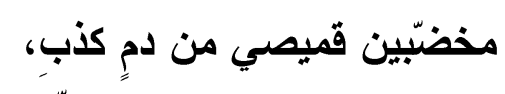

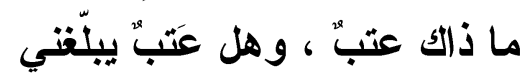




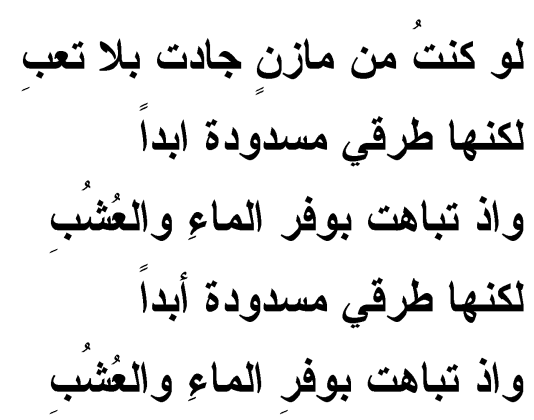

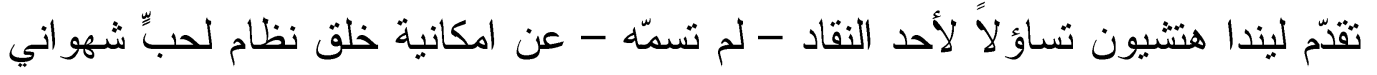
جديد من غير اعادة استعمال النظام القديم بطريقة من الطرق وتجاوز جميع أنثكال التعبير

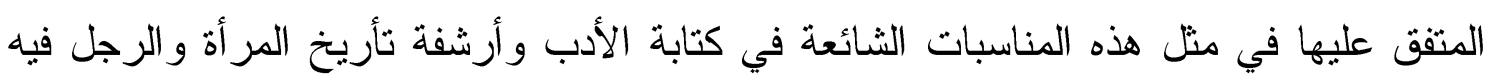

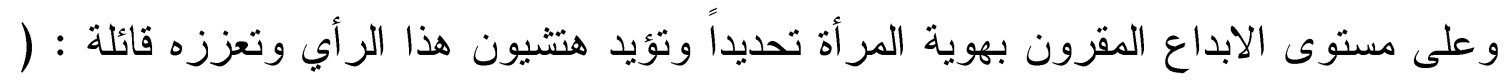

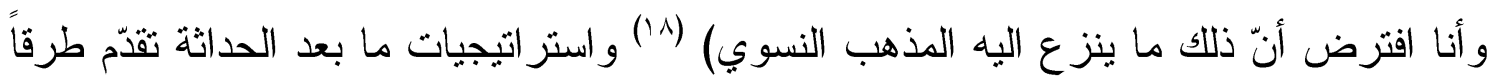

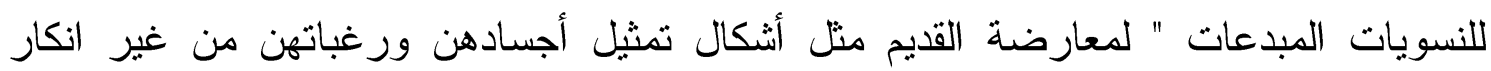

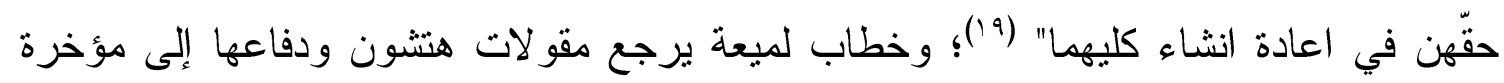
قناعاته، فالنظرية لايها شيء والتطبيق آخر، وتمضي لأجل ذلك الأبياء لأبيات المسجلة في ترشيح

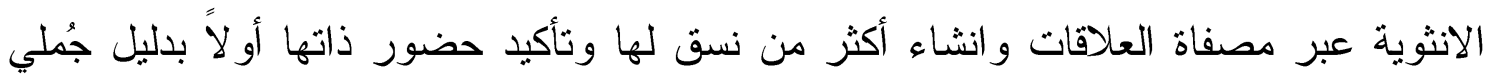

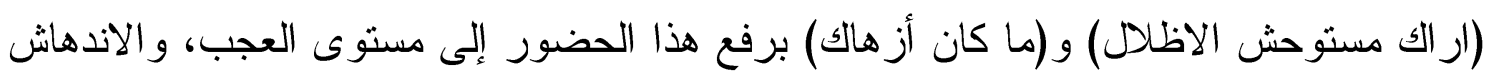

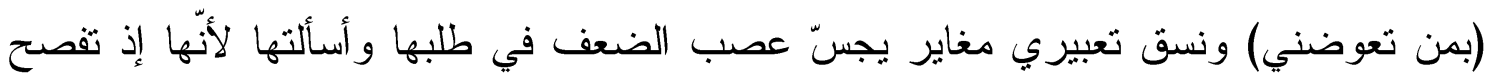

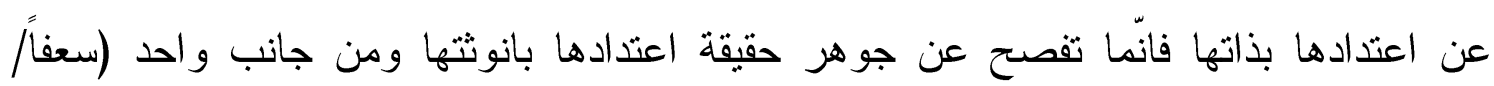

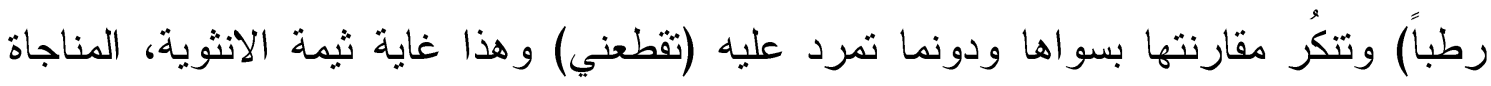

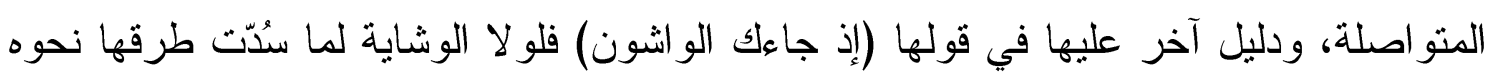

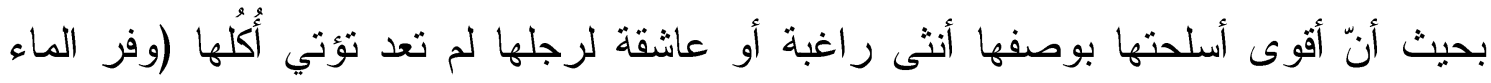
و العشب).

فتلك الثرة التي تطرح رطباً جنياً تعتمد على مخيال تعبوي قديم ترستخه الثاعرة في

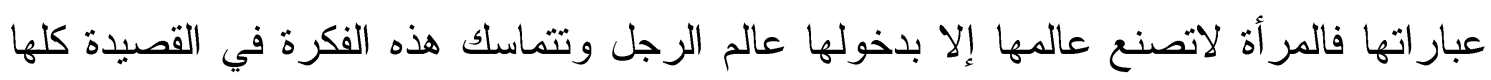

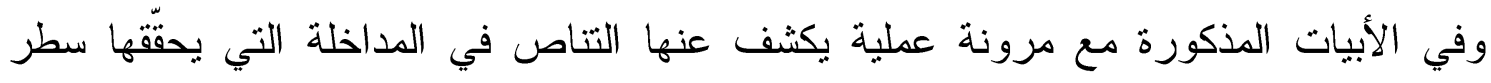

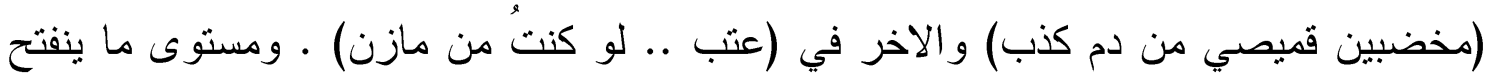

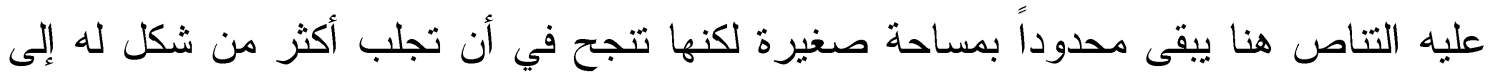

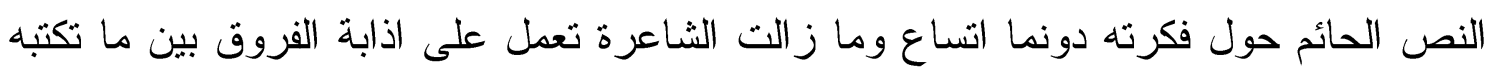
الأنثى من ابداع وما تحققه هوية الجسد لدى المرأة من خصوصية في الكتابة وترميز به وتلويح 
بأهميته بوصفه اختيارًا ملائماً لأنثوية الكاتبة، وتبدو المماهاة بين لغة الجسد ولغة الثاعرة جلية كذلك في نصيّها (لو أنبأني العرّاف) فنقر أها - أبي المماهاة - في خمسة مقاطع يمثلها نسق يعتمد

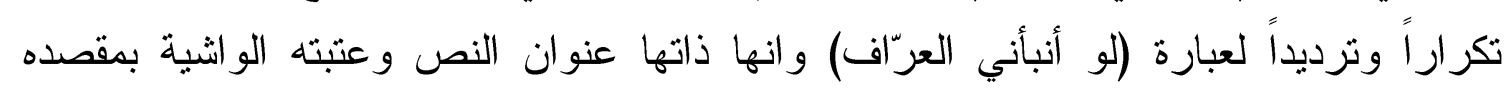
ودلالته الرئيسة وهكا تترتّب أجزاء القصبدة كالآتي:

$$
\begin{aligned}
& \text { ا ـ لو أنبأني العراف + ع اسطر } \\
& \text { r. لو أنبأني العراف + r أسطر } \\
& \text { r. لو أنبأني العر اف + ع اسطر } \\
& \text { ع. لو أنبأني العراف + ع اسطر } \\
& \text { ๑. لو أنبأني العراف + ه اسطر }
\end{aligned}
$$

تقول الشاعرة:

ا. لو أنبأني العراف / أنك يوماً ستكون حبيبي/ لم اكتب غزلاً في رجل / خرساء اصلّي/ لتظلّ حبيبي. و هذا كثف عن شدة احتياجها الى الآخر وتلاشي كينونتها فيه فلا وجود لها خارج حدود عالم الرجل المخاطب. r. لو أنبأني العراف/ أني سألامس وجه القمر العالي/ لم العب بحصى الغدران/ ولم

$$
\text { أنظم من خرز آمالي. }
$$

وهنا صورة أخرى عن حسية الرغبة ونوع العاطفة وثمة لقطة حية نتمكن من رصدها

بين اللمس و اللعب و النظم؛ والمتكلمة تريد الافصاح عن تجربة خاصة وتبتعد عن امكانية تعميم موضوعها لكسر رهاب الذاتية وسطوة الحماسة الغنائية، نريد بتعميم موضوعها انّها ربما اخرجت الانثوية إلى ذوات نساء اخريات فتصبح المسألة موضوعة عامة تهم جنساً بتمامه، وتفرز فكرة النص ايقونة الضمير المستعمل (تاء المتكلمة) ابتداء من ياء المفعول في (أنبأني) وتنوع مفرداتي لضمير المتكلمة في نص قصير تتردد فيه مفردة (حبيبي) اربع مرات + (اميراً)

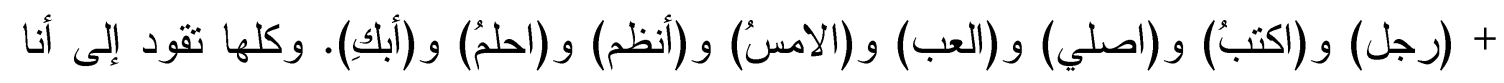

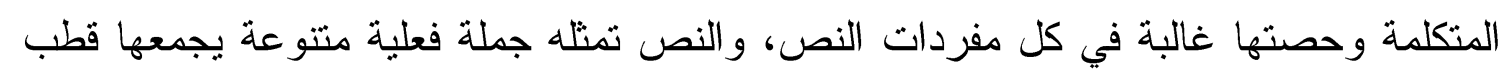
لساني أوحد هو جملة الشرط، فاذ يمتتع الفعل يمتتع الجواب لتبقى احتياجات المتكلمة دائرة في مسار علاقة امر أة برجل غائب أو هاجر أو قاطع ودّها باختيار يعلنه خطابها الشعري طوال 


\section{الاحالات و الهو امش}

ينظر الجنس الآخر، سيمون دي بوفوار، تر : مجموعة من الأساتذة، ص. r. نفسه، ص لو 19.

سياسة ما بعد الحداثية، لينداهنشيون، تر : د. حيدر حاج إسماعيل ، در اجعـة:

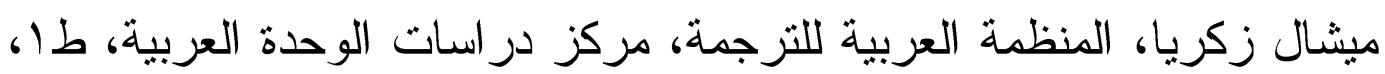

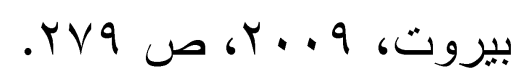

نفسه.

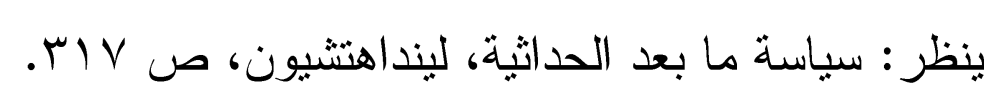

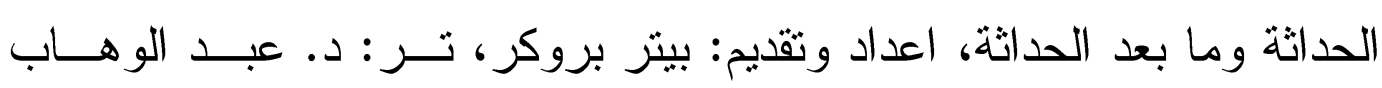

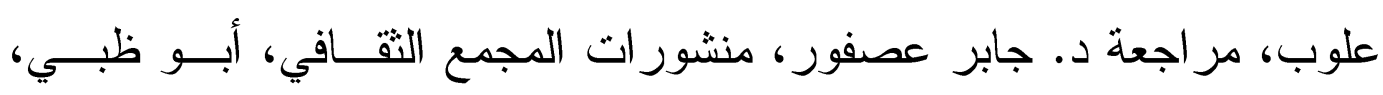

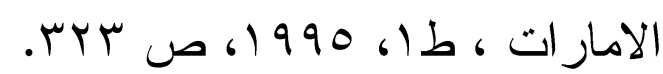

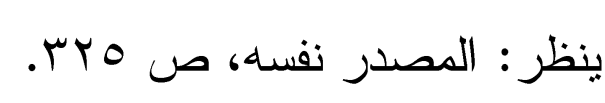

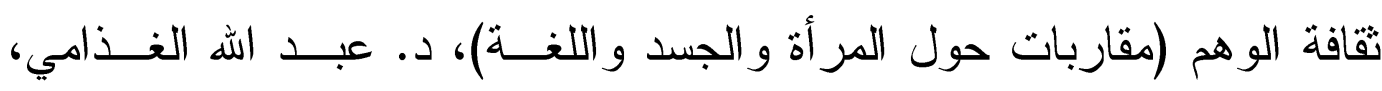

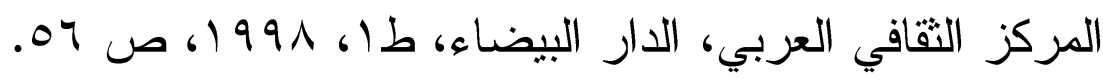

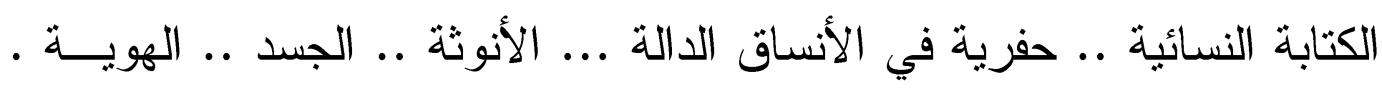

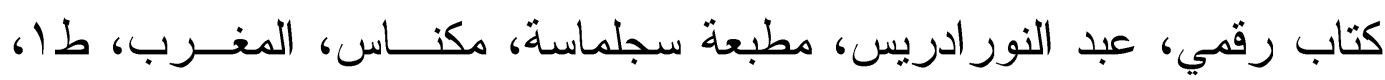

$$
\text { צ. . . T، ص זr7. }
$$

هسهـة اللغة ، رولان بارت، تزجمة ، د. دنــذر عياثــي، مركــز الانمــاء

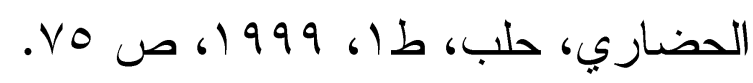

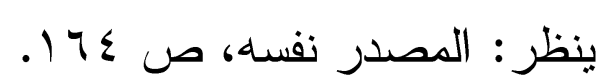

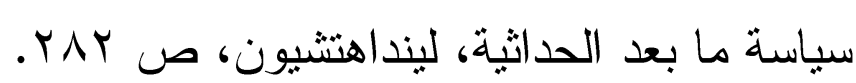


ينظر : مجلة انزياحات، بحث بعنوان ، نحو اســتاطيقيا جماليــة نقديــة فـــي

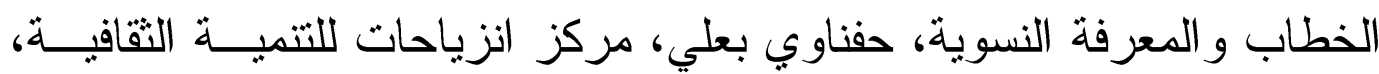

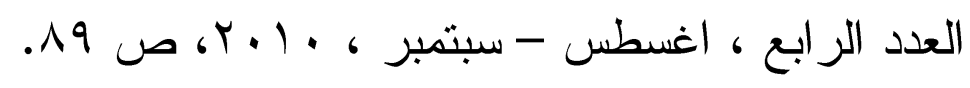

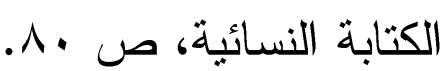

نخلة العر اق الثـامخة، لميعة عباس عمارة، قصي الفرضي، موقع الكترونــي،

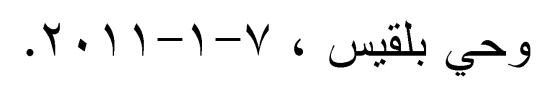

WWw.alganabi.com

لو أنبأني العر اف ، مجموعة شعرية ، لميعة عباس عمارة، المؤسسة العربيــة

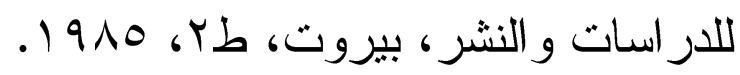

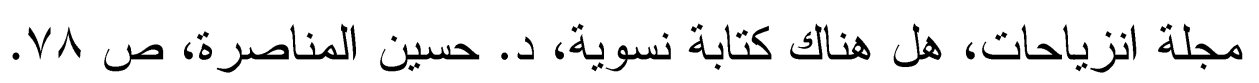

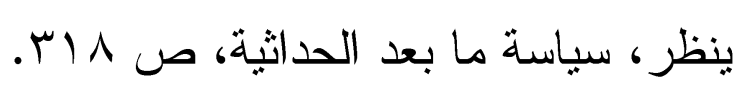


( (1)ثقافة الوهم ( مقاربات حول المر أة و الجسد و اللغة )، د. عبـــــاله الغـــامي ، المركــز

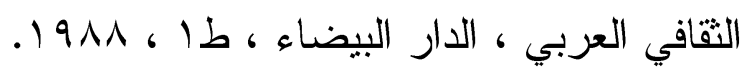

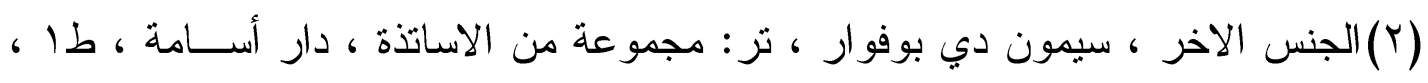

(r) الحداثة وما بعد الحداثة ، اعداد وتقديم : بيتر بروكر ، ترجمة : د. عبد الوهاب علوب

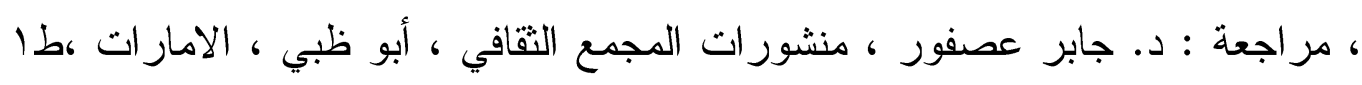

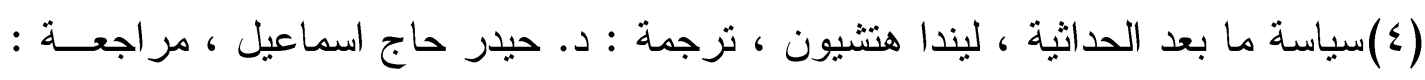

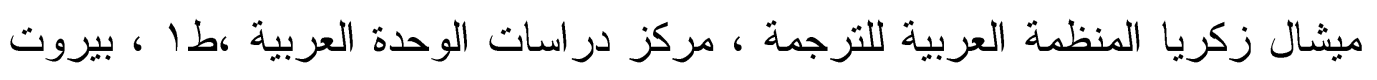

$$
\text { . r... ، }
$$

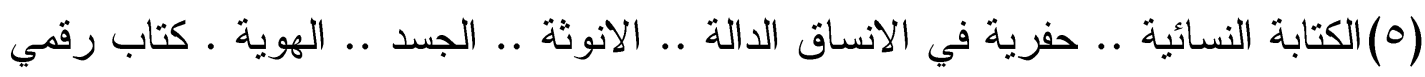

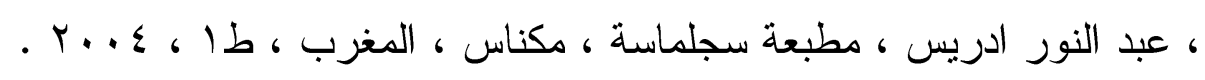

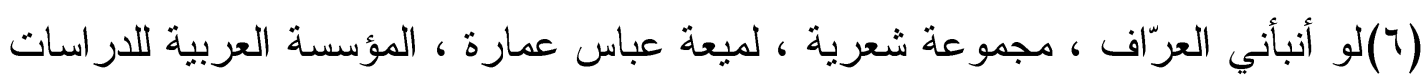

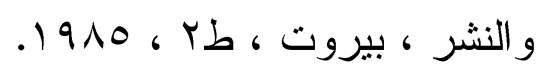

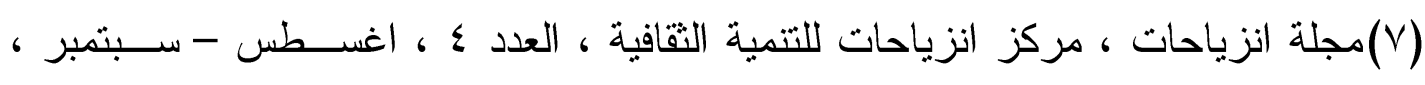
. r. . .

(^)نخلة العراق الثامخة ، لميعة عباس عمارة ، قصي الفرضي ، موقع الكتروني ، وحي

$$
\text { بلقيس }
$$

www.

Alganabi.com

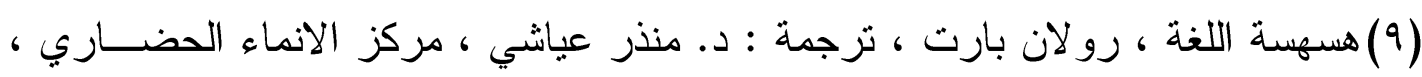


Question of gender and feminist culture of creativity arab ( Lemeea Abbas amara a model)

Assistant professor DR. ansam Muhammad Rasid Baghdad university, college of education,Ibn rushd ( Abstract)

Department of arabic

Divided we discussed the question of gender on two complementary moving the first of them to read critical discourse feminist and accountability concepts of the major private gender and follow the development of this term and the role of feminist criticism in establishing the identity of creative for women and writing a man in a great desire to smash the patriarchy dominating all aspects of life including movement and creativity of writing. And wants our search in the segment complementary to dismantle what gender over the creative experience of arab and chose the experience of the poet Iraqi lemeea abbas amara poet pilot did not take her experience creative at large share an analytical and critical suitable for decades of creativity one who wrote about lemeea few does not meet maturely produced poetry and try to respond to our vision and our analysis for, inter alia, that itreminded her of a mature hair line pen 